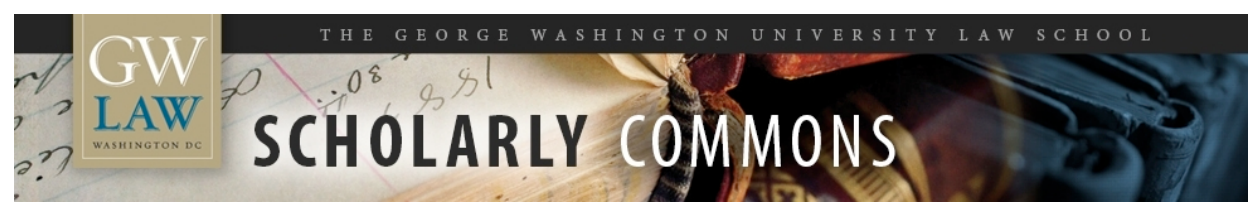

\title{
Cooperative Judicial Nominations During the Obama Administration
}

David Fontana

George Washington University Law School, dfontana@law.gwu.edu

Follow this and additional works at: https://scholarship.law.gwu.edu/faculty_publications

Part of the Law Commons

\section{Recommended Citation}

Fontana, David, Cooperative Judicial Nominations During the Obama Administration (March 28, 2017). Wisconsin Law Review, Forthcoming; GWU Law School Public Law Research Paper No. 2017-24; GWU Legal Studies Research Paper No. 2017-24. Available at SSRN: https://ssrn.com/abstract=2942297

This Article is brought to you for free and open access by the Faculty Scholarship at Scholarly Commons. It has been accepted for inclusion in GW Law Faculty Publications \& Other Works by an authorized administrator of Scholarly Commons. For more information, please contact spagel@law.gwu.edu. 


\title{
COOPERATIVE JUDICIAL NOMINATIONS DURING THE OBAMA ADMINISTRATION
}

\author{
DAVID FONTANA*
}

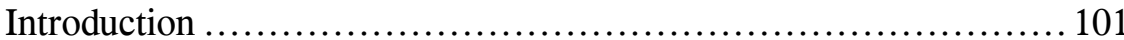

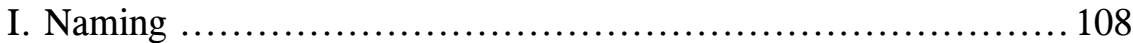

II. Numbing ...................................................... 124

III. Numbers .................................................. 130

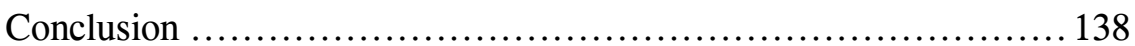

INTRODUCTION

During his eight years in office, President Barack Obama changed the face of the federal judiciary. A total of 331 of his federal judicial nominees were confirmed, a larger number (by one) than President George W. Bush had confirmed during his eight year term. ${ }^{1}$ At the time that Donald J. Trump became the President of the United States in January of 2017, approximately two-thirds of federal district court judges and approximately half of federal circuit judges had been nominated by Democratic presidents. ${ }^{2}$ Several Obama nominees have the promise to be major voices on the federal bench for decades to come. ${ }^{3}$ President Obama successfully nominated two justices to the

\footnotetext{
* $\quad$ Associate Professor of Law, George Washington University School of Law. My thanks to the Wisconsin Law Review for their invitation to participate in this symposium. A disclaimer: I participated in various capacities in many of these nominations controversies, and have written about many of them for popular audiences. One of the goals of this Essay is to provide some theoretical heft to tie together a lot of what I have been doing for and writing about for larger audiences. For their comments on this Essay, I would like to thank Michael Abramowicz, Thomas Colby, Aziz Huq, Orin Kerr, and Peter Smith. For many discussions over the years on these issues, special thanks to Micah Schwartzman.

1. See Judgeship Appointments by President, U.S. CTS., http://www.uscourts.gov/sites/default/files/apptsbypres_0.pdf [https://perma.cc/5RNL6452] (last visited Mar. 12, 2017).

2. $\quad$ Philip Rucker \& Robert Barnes, Trump to Inherit More Than 100 Court Vacancies, Plans to Reshape Judiciary, WASH. PosT (Dec. 25, 2016), https://www.washingtonpost.com/politics/trump-to-inherit-more-than-100-courtvacancies-plans-to-reshape-judiciary/2016/12/25/d190dd18-c928-11e6-85b576616a33048d_story.html?utm_term =.dce24dc0ebe5 [https://perma.cc/GG79-EEAK].

3. See David Fontana, Obama Has Started Making Major Progress on Nominating Judges-and This Is His Most Important One Yet, NEw REPUBLIC (May 13, 2014), https://newrepublic.com/article/117747/pamela-harris-fourth-circuit-court-whyliberals-should-cheer-her [https://perma.cc/E3E7-HNLP] (identifying Fourth Circuit Judge Pamela Harris as an important nominee); David Fontana, Obama's Shocking
} 
Supreme Court, both of whom (in different ways) have the potential to contribute to the liberal jurisprudential cause for many years to come. ${ }^{4}$ President Obama's federal judicial nominees were the most diverse along many dimensions of any president in the history of the United States. ${ }^{5}$ Some of these accomplishments were made possible by the controversial decision by Senate Democrats in 2013 to abolish the filibuster for lower court nominations. ${ }^{6}$

The perfect should not be the enemy of the good, but the good enough should not distract progressives from what could have been better for their judicial agenda. President Obama did a lot for the federal courts, but could have done more. President Trump inherited 103 judicial vacancies from President Obama, almost twice the amount President Obama inherited from President George W. Bush. ${ }^{7}$ Empirical measures suggest that President Obama's nominees were more moderate, as compared to the more ideologically conservative nature of the nominees of past Republican presidents. ${ }^{8}$ This was true even after

Success on Judicial Nominations Overturns Conventional Wisdom, DAILY BEAST (June 9, 2014, 4:45 AM), http://www.thedailybeast.com/articles/2014/06/09/obama-sshocking-success-on-judgeships-overturns-conventional-wisdom.html [https://perma.cc/7C4Q-PC5G] (identifying First Circuit Judge David Barron, Ninth Circuit Judge Michelle Friedland, and Southern District of New York Judges Jesse Furman and Allison Nathan as future liberal judicial superstars).

4. See David Fontana, The Obama Justices: Sonia Sotomayor and Elena Kagan Represent Conflicting Styles of Liberalism-Or Are They Complementary?, SLATE (Jan. 13, 2015), http://www.slate.com/articles/news_and_politics/jurisprudence/2015/01/obama_s_supre me court justices elena kagan and sonia sotomayor have elite.html [https://perma.cc/X9U7-FV3E].

5. See Donna Owens, Obama's Legacy on Judicial Appointments, By the Numbers, NBC NEws (Jan. 19, 2017, 9:21 PM), http://www.nbcnews.com/storyline/president-obama-the-legacy/obama-s-legacyjudicial-appointments-numbers-n709306 [https://perma.cc/CD58-VWLX] ("The more than 300 Obama-nominated judges are considered to be the most diverse group in U.S. history in terms of terms of gender, ethnicity, and nationality.").

6. See Jeremy $\mathrm{W}$. Peters, In Landmark Vote, Senate Limits Use of the Filibuster, N.Y. TIMES (Nov. 21, 2013), http://www.nytimes.com/2013/11/22/us/politics/reid-sets-in-motion-steps-to-limit-useof-filibuster.html [https://perma.cc/5WYL-SLK7].

7. $\quad$ Rucker \& Barnes, supra note 2.

8. See Corey Rayburn Yung, Judged By The Company You Keep: An Empirical Study of the Ideologies of Judges on the United States Courts of Appeals, 51 B.C. L. Rev. 1133, 1133 (2010) ("[I]n general judges appointed by Republican presidents were more ideological than those appointed by Democratic presidents."); Neal Devins \& Lawrence Baum, Split Definitive: How Party Polarization Turned the Supreme Court Into A Partisan Court, 2016 SuP. CT. REV. (forthcoming 2017) (manuscript at 6) ("Our analysis shows that the growing ideological gap between Democratic-appointed justices and Republican-appointed justices is largely attributable to the appointment of conservative Republican nominees."). 
the elimination of the Senate filibuster constrained the Republican Senators for two years (before they took back the Senate majority). ${ }^{9}$

Many of the superstars of the liberal legal movement often identified as having transformative potential-Pamela Karlan or Goodwin Liu, to name two-remain either not on the bench at all or were appointed by Democratic Governors to state judicial positions. ${ }^{10}$ Consider, by contrast, that during the terms of the past three Republican presidents, many of the most jurisprudentially influential (and youngest) conservative lawyers had been successfully nominated to the federal bench. ${ }^{11}$

This Essay argues that the tactical roots of these failures to do more on judicial nominations during the Obama Administration reside in a common tactical error made by political leaders in the Democratic Party: excessive cooperation with political forces that do not manifest the same behavioral patterns of cooperation. ${ }^{12}$ The Obama

9. See Christina L. Boyd, Michael S. Lynch \& Anthony J. Madonna, Nuclear Fallout: Investigating the Effect of Senate Procedural Reform on Judicial Nominations, 13 FORUM 623 (2015).

10. See Howard Mintz, Goodwin Liu Confirmed to California Supreme Court, MERCURY NEWs (Aug. 31, 2011, 10:21 AM), http://www.mercurynews.com/2011/08/31/goodwin-liu-confirmed-to-californiasupreme-court/ [https://perma.cc/Z4GJ-JDVG]; Jeffery Toobin, A Sharp Progressive Joins the D.O.J., NEW YORKER (Dec. 20, 2013), http://www.newyorker.com/news/news-desk/a-sharp-progressive-joins-the-d-o-j [https://perma.cc/3G6M-5LDU].

11. See David Fontana \& Micah Schwartzman, Old World, New RePubLIC (July 17, 2009), $\quad$ https://newrepublic.com/article/62573/old-world [https://perma.cc/XEY4-PPAD] ("[R]oughly a quarter of the circuit-court nominees put forward by the past three Republican presidents . . . were below the age of 45 . Reagan nominated some of the brightest young legal minds in the country, including Alex Kozinski (then 34), Frank Easterbrook (36), Kenneth Starr (37), J. Harvie Wilkinson (39), Doug Ginsburg (40), and Richard Posner (42). The first President Bush nominated Michael Luttig (36), Samuel Alito (39), and Clarence Thomas (41). And George W. Bush continued this practice, nominating Neil Gorsuch (38), Brett Kavanaugh (41), Raymond Kethledge (41), Jeffrey Sutton (42), and William Pryor (42), among others.”).

12. For a general discussion of the differing organizational purposes of the two political parties, and the behavioral manifestations of these differences, see MATT Grossmann \& DAvid A. Hopkins, Asymmetric Politics: IDEOlOGicAl RePublicans and Group Interest Democrats (2016); Jo Freeman, The Political Culture of the Democratic and Republican Parties, 101 PoL. SCI. Q. 327 (1986); Matt Grossmann \& David A. Hopkins, Ideological Republicans and Interest Group Democrats: The Asymmetry of American Party Politics, 13 PERSP. ON POL. 119 (2015). See also Matt Grossmann \& David A. Hopkins, More Proof That Republicans Are From Mars and Democrats Are From Venus, WASH. Post (Mar. 20, 2015), https://www.washingtonpost.com/news/monkey-cage/wp/2015/03/10/more-proof-thatrepublicans-are-from-mars-and-democrats-are-from-venus $/$ ?utm_term $=. \mathrm{a} 965 \mathrm{c} 8 \mathrm{ad} 357 \mathrm{e}$ [https://perma.cc/P79Q-8JJ5] (summarizing this research by stating that "[t]he Republican Party . . . is best understood as the agent of an ideological movement dedicated to advancing the cause of conservatism. . . . The Democratic Party, in 
Administration did not avail itself of a supply side of uncooperative tools used to approach judicial nominations, and focused mostly on cooperative approaches to judicial nominations. The Obama Administration's approach to judicial nominations, in other words, featured asymmetric usage of "constitutional hardball"13 or "constitutional showdowns." ${ }^{14}$ In addition to the tactical argument, this Essay has a taxonomical goal. Judicial nominations are a unique field of political activity, ${ }^{15}$ in which a series of more aggressive political strategies have emerged, yet have not previously been identified and described. For both the tactical and the taxonomical, the goal is to take a step back from the day-to-day politics of judicial nominations to make some larger, more theoretical observations about the eight years of judicial nominations by the Obama Administration that will shed some light to inform later presidencies.

In game theoretic terms, the closest way to explain this would be as follows. Engaging in a non-cooperative strategy with a cooperative opponent yields a suboptimal result. ${ }^{16}$ There are not the political costs

contrast, is best understood as a coalition of social groups seeking various forms of government action. Most Democratic supporters in the mass public are attracted to the party for reasons of group interest or identity rather than a devotion to the principles of liberalism."). In the context of judicial nominations, see Lawrence Baum \& Neal Devins, Ideological Imbalance: Why Democrats Usually Pick Moderate-Liberal Justices and Republicans Usually Pick Conservative Ones, Slate (Mar. 17, 2016, 2:33 PM), http://www.slate.com/articles/news_and_politics/jurisprudence/2016/03/democrats_alw ays_pick_moderates_like_merrick_garland.html [https://perma.cc/B77D-GXAU] ("Democrats Bill Clinton and Barack Obama were careful to choose nominees who stood on the liberal side of the ideological spectrum. But at the same time, they veered away from candidates whose strong liberalism would prompt confirmation battles and toward nominees who embraced the rhetoric of judicial restraint, had rich personal histories, and were perceived as less ideological.").

13. Mark Tushnet, Constitutional Hardball, 37 J. Marshall L. ReV. 523, 523 (2004) (defining constitutional hardball as "consist[ing] of political claims and practices that are without much question within the bounds of existing constitutional doctrine and practice but that are nonetheless in some tension with existing preconstitutional understandings").

14. Eric A. Posner \& Adrian Vermeule, Constitutional Showdowns, 156 U. PA. L. REV. 991, 997 (2008) (defining constitutional showdowns as featuring "a disagreement between branches of government over their constitutional powers that ends in the total or partial acquiescence by one branch in the views of the other and that creates a constitutional precedent").

15. A sociologist would refer to judicial nominations as a "field." See Neil Fligstein, The Theory of Fields and Its Application to Corporate Governance, 39 SeAtTle U. L. Rev. 237, 242 (2016) (featuring a description by a leading sociologist of a field as a "socially constructed arena[] within which individuals or groups with differing resource endowments vie for advantage") (citations omitted).

16. See Louis Kaplow, On the Meaning of Horizontal Agreements in Competition Law, 99 CALIF. L. REv. 683, 781-82 (2011) (summarizing the difference between cooperative and non-cooperative games as being that "all noncooperative 
for being aggressive that existed before our age of polarization, and indeed there are political benefits to being aggressive. Because the violation of cooperative norms generates a greater backlash by opponents and supporters alike-without the political resources necessary to overcome those greater political costs-non-cooperative strategies fail in a largely cooperative environment for three related reasons. ${ }^{17}$ In the context of judicial nominations, the assumption was that Republican Senators and affiliated interest groups were not engaged in "empire-building government." 18 A more aggressive strategy by the Obama Administration would therefore have generated additional political costs by antagonizing the opposition. ${ }^{19}$ Second, these direct political costs generate additional opportunity costs. $^{20}$ Political resources spent overcoming Senate obstruction-both public and private $^{21}$-are political resources not spent on ensuring the enactment of the Patient Protection and Affordable Care Act to provide health care

games . . . must be described as involving no agreement. . . . [I]f there is an agreement, we by definition have a cooperative game, but it was stipulated that the game is noncooperative").

17. See David Fontana \& Donald Braman, Judicial Backlash or Just Backlash? Evidence From A National Experiment, 112 Colum. L. Rev. 731, 766 (2012) (identifying the arguments behind cooperative strategies).

18. Daryl J. Levinson, Empire-Building Government in Constitutional Law, 118 HARV. L. REV. 915, 916 (2005) (“A[n] . . . enduring and pervasive assumption in constitutional law and theory is that much government behavior is driven by empirebuilding, the self-aggrandizing pursuit of power or wealth.").

19. See, e.g., Neil A. Lewis, Moderate Is Said To Be Pick for Court, N.Y. TIMES (Mar. 17, 2009), http://www.nytimes.com/2009/03/17/us/politics/17nominate.html [https://perma.cc/S67Z-WDEL] ("The administration official said part of the reason for making the [David] Hamilton nomination [to the Seventh Circuit] the administration's first public entry into the often contentious field of judicial selection was to serve 'as a kind of signal' about the kind of nominees Mr. Obama will select. The official spoke on the condition of anonymity because the nomination had not been officially made."); Jeffrey Toobin, Bench Press, NEW Yorker (Sept. 21, 2009), http://www.newyorker.com/magazine/2009/09/21/bench-press

[https://perma.cc/RZ7Z-258J] ("The hope was that Hamilton's appointment would begin a profound and rapid change in the confirmation process and in the federal judiciary itself.").

20. See Michael Grunwald, Did Obama Win the Judicial Wars?, Politico (Aug. 8, 2016, 5:25 AM), http://www.politico.com/story/2016/08/obama-courtsjudicial-legacy-226741 [https://perma.cc/YE7E-BN2J] (noting that "Obama's first chief of staff, Rahm Emanuel, made it clear internally that he didn't want to waste precious political capital on polarizing judges").

21. See Catherine Fisk \& Erwin Chemerinsky, The Filibuster, 49 STAN. L. REV. 181, 206 (1997) ("In most cases, the two-track system keeps filibusters out of the public eye."); $i d$. at 181 ("Filibusters are ubiquitous but virtually invisible, for the contemporary Senate practice does not require a senator to hold the floor to filibuster; senators filibuster simply by indicating to the Senate leadership that they intend to do so."). 
or a stimulus package to protect the economy. Third, the assumption is that there is not the same political energy and therefore not the same political resources within the Democratic Party on judicial nominations to overcome political costs as there is in the Republican Party. ${ }^{22}$ Aggressive strategies generate new political enemies and no new-but much needed-political friends.

However, judicial nominations have increasingly become a noncooperative environment in which non-cooperative strategies fare better. Now that both political parties are increasingly polarized, the incentives to cooperate with the other political party are much lower. ${ }^{23}$ The result is that more and more fields of political action are dominated by political parties that do not respect traditional written and unwritten norms of cooperation. In this environment, non-cooperative strategies perform increasingly better. More aggressive strategies to accomplish more transformative outcomes generate the same political costs in terms of opposition as do less aggressive strategies. More aggressive strategies generate more political resources in terms of active and engaged support from political allies.

The tactical argument for the possibilities generated by more aggressive approaches to judicial nominations is made in the context of a series of identifiable practices towards judicial nominations that have emerged in past presidential administrations, yet were relatively underutilized during the Obama Administration. These tactical tools are helpful whether the task is nominating a district court judge, a circuit court judge, or a Supreme Court Justice, and are helpful when controlling the Senate or facing a Senate controlled by the opposition party.

I label these three tactical tools-visible outside of the nominations context as well-as naming, numbing, and numbers. Naming means an Administration selecting nominees that identify their jurisprudential perspective with a particular frame-such as originalism-and promoting these nominees by also using that name. Numbing means the open consideration and/or selection of unusually provocative judicial nominees that generate political extremeness aversion. The political

22. See Richard A. Posner, Justice Breyer Throws Down the Gauntlet, 115 YALE L.J. 1699, 1699 (2006) ("In recent years, the initiative in constitutional debate has passed to the conservatives .... The liberals continue to win a significant share of victories, in such areas as homosexual rights, affirmative action, and capital punishment, but for the most part their stance, their outlook, has been defensive: defense of the Warren Court and Roe v. Wade.").

23. See Daryl J. Levinson \& Richard H. Pildes, Separation of Parties, Not Powers, 119 HARV. L. REV. 2311, 2332 (2006) (“[T]he two major parties today are as coherent and polarized as they have been in perhaps a century, and for reasons that are likely to endure."). 
system is distracted from other nominees by the controversial political or actual nominee, and other nominees are framed as less controversial because their views are distorted by comparison to the controversial potential or actual nominees. Numbers refers to the simultaneous nomination of a large number of judges to the federal bench. The volume of nominees precludes the opposition from being able to direct resources towards a critical mass of nominees, and also generates political pressure to confirm a critical mass so as to avoid being labeled as obstructing the Senate.

Two caveats are worth making. First, it could be that the Obama Administration's record on judicial nominations was a purposefully lost opportunity, in that the nature and number of its nominees reflected genuinely revealed preferences of the President leading the efforts of the Administration. President Obama himself wrote before becoming President ${ }^{24}$-and indicated when he was President ${ }^{25}$ - that he was quite content with a more limited role for the federal courts and therefore a more limited focus on judicial nominations. Scholars affiliated with the political left had spent at least a decade before President Obama took office in 2009 exploring the theoretical merits of "taking the Constitution away from the courts" 26 and focusing increasingly on popular constitutionalism. ${ }^{27}$ The Obama Administration, though, featured its share of cause lawyers inside the Administration and liberal groups outside of the Administration advocating for efforts to shape the federal bench. ${ }^{28}$ Later Democratic Administrations surely will feature those constituencies as well. This Essay is meant to provide a tactical roadmap to frame their approach.

24. See Barack OBama, The Audacity of Hope: Thoughts ON RECLAIMING THE AMERICAN DREAM 83 (2006) ("[I]n our reliance on the courts to vindicate not only our rights but also our values, progressives had lost too much faith in democracy.").

25. See Jeffrey Toobin, The Obama Brief: The President Considers His Judicial Legacy, NEW YORKER (Oct. 27, 2014),

http://www.newyorker.com/magazine/2014/10/27/obama-brief

[https://perma.cc/R4NG-YREY] (quoting Obama as stating that "[t]he bulk of my nominees, twenty years ago or even ten years ago, would have been considered very much centrists, well within the mainstream of American jurisprudence, not particularly fire-breathing or ideologically driven").

26. See Mark Tushnet, TAKing the Constitution Away from the COURTS (1999).

27. See Robert Post \& Reva Siegel, Popular Constitutionalism, Departmentalism, and Judicial Supremacy, 92 CALIF. L. REV. 1027, 1043 (2004) ("The danger of judicial supremacy is not that the people will be deprived of the authority to decide a particular case, but rather that they will cease to maintain a vibrant and energetic engagement with the process of constitutional self-governance.").

28. See Margo Schlanger, Offices of Goodness: Influence Without Authority in Federal Agencies, 36 CARdozo L. REV. 53, 115 (2014). 
Second, this Essay is about the boundaries of the possible, not the desirability of the possible. The goal is to identify the possibilities for Democratic Presidents wishing to prioritize judicial nominations, and the tactical approaches to achieve these possibilities that are often neglected in scholarly and public discussions. Identifying more aggressive strategies that could have worked is not the same as saying these strategies should be utilized all things considered. A complete normative evaluation of uncooperative approaches to judicial nominations would have to consider, for instance, whether uncooperative behavior is justified as a tactical response to initially uncooperative behavior, or whether the damage to our institutional norms generated by any uncooperative behavior is too great. ${ }^{29}$

\section{NAMING}

Judicial nominations are a unique occasion to define and promote the jurisprudential vision that a presidential administration desires-to name that vision. The large stakes involved in judicial nominations means that nominations serve as a focal point to coordinate legal activities and construct a name for the associated jurisprudential vision. The microphone provided by the stakes of judicial nominations provides an occasion to promote that name and the associated jurisprudential vision. Naming does not generate any additional opposition to nominees in the Senate, because senators will often pin names on nominees not deserving of such labels. Naming does, though, mobilize political resources behind a judicial nominee and the President promoting that nominee.

The act of naming the jurisprudential vision that a presidential administration wishes to promote is a crucial part of promoting the success of that jurisprudential vision. Scholars in the social sciences have often referred to this act of naming as constructing a "frame," or a "schemata of interpretation" that encourages people to "locate, perceive, identify and label" experiences and events into a coherent whole. ${ }^{30}$ Framing a jurisprudential vision in terms of a singular name "provide[s] a grammar that punctuates and syntactically connects

29. The larger theoretical issue this raises was framed by David Pozen's important article. See David E. Pozen, Self-Help and the Separation of Powers, 124 YALE L.J. 2, 5 (2014) (considering "when . . . officials in one branch of the federal government [can] attempt to redress another branch's perceived wrong through means that, but for that wrongdoing, would be impermissible").

30. ERVING GofFMan, Frame Analysis: An EsSAy on the Organization OF EXPERIENCE 21 (1974). 
patterns or happenings in the world." ${ }^{31}$ This name will provide a diagnosis (what past wrong the new vision is trying to remedy), a prognosis (identifying the tools that will be used to implement that remedy), and a motivation (suggesting why the stakes of this remedy are so important). ${ }^{32}$

Naming plays several constructive roles for a presidential administration. Administrations rely on tools like the Office of Information and Regulatory Affairs (OIRA) to coordinate executive actions. ${ }^{33}$ Naming plays a similar function as an OIRA directive: it minimizes agency costs within a presidential administration by suggesting to disparate officials within the administration what the legal ambitions of the administration are. The lawyer in the White House evaluating nominees to the federal courts and the lawyer arguing a case from the Civil Appellate Division of the Department of Justice both know they are bound by the jurisprudential vision reflected in that name. ${ }^{34}$ Names can feature ambiguities, to be sure, but administrations can engage in efforts to remove those ambiguities and ensure a more faithful implementation of the jurisprudential vision. The most dramatic illustration of this was promulgation by the Office of Legal Policy in the Department of Justice during the Reagan Administration of the Guidelines on Constitutional Litigation and The Constitution in the Year 2000: Choices Ahead in Constitutional Interpretation, both of which provided more granular guidance to the executive branch about constitutional choices. ${ }^{35}$

Naming tries to persuade members of the public of the merits of the jurisprudential vision of the presidential administration. ${ }^{36}$ Members

31. See David A. Snow \& Robert D. Benford, Master Frames and Cycles of Protest, in Frontiers in Social Movement Theory 133, 138 (Aldon D. Morris \& Carol McClurg Mueller eds., 1992).

32. Robert D. Benford \& David A. Snow, Framing Processes and Social Movements: An Overview and Assessment, 26 ANN. REv. Soc. 611, 615 (2000).

33. See Elena Kagan, Presidential Administration, 114 Harv. L. Rev. 2245, 2277-90 (2001).

34. See Steven M. Teles, Transformative Bureaucracy: Reagan's Lawyers and the Dynamics of Political Investment, 23 STUD. AM. POL. DEV. 61, 66 (2009) (noting how the Reagan Administration used the originalism vision to coordinate personnel selection and action across the government).

35. For a discussion of the nature and significance of these documents, see Dawn E. Johnsen, Ronald Reagan and the Rehnquist Court on Congressional Power: Presidential Influences on Constitutional Change, 78 IND. L.J. 363 (2003); Reva B. Siegel, Dead or Alive: Originalism as Popular Constitutionalism in Heller, 122 HARV. L. REV. 191, 221-23 (2008).

36. See Jamal Greene, Selling Originalism, 97 GEO. L.J. 657, 703 (2009) (noting how the ultimate goal of these names is to generate "prestige and . . . corral and preserve the majorities necessary to distribute her constitutional ideas"); Dan M. Kahan, The Supreme Court 2010 Term: Foreword: Neutral Principles, Motivated 
of the public do not have the interest or the aptitude to engage in sophisticated analysis of complicated jurisprudential debates, so the name attached to a position can be important. ${ }^{37}$ The name constructs what arguments are considered "on the wall" and "off the wall." 38 The mere fact that those in power are using this name and grouping arguments together with that name moves the jurisprudential debate in the direction of that name by dominating the public debate about legal issues. ${ }^{39}$

Scholars such as Reva Siegel and Steven Teles have, for instance, identified the role that originalism plays as a name both to identify the problems with the Warren Court and to promote the alternative approach to judging that Republican presidents have supported. ${ }^{40}$ Conservatives organized around originalism as the name for what the Warren Court lacked and what a new Reagan or Bush-dominated lower court judge or Supreme Court Justice would utilize. ${ }^{41}$ Justice Antonin Scalia argued that "it takes a theory to beat a theory," 42 and indeed liberals have debated and designed their own alternative names for what

Cognition and Some Problems for Constitutional Law, 125 HARv. L. REv. 1, 74 (2011) (noting how these names serve as "signals that are received by intermediary groups including politicians and media commentators - who then amplify and retransmit them to members of the cultural groups who look to them for guidance").

37. See Greene, supra note 36, at 710 ("So too the language of originalism, and particularly its appeal to scientific norms, satisfies a public demand for a digestible means of muting conflict over unresolved issues of constitutional law.") (citations omitted).

38. See Jack M. Balkin, How Social Movements Change (or Fail to Change) the Constitution: The Case of the New Departure, 39 Suffolk U. L. REv. 27, 30, 52 (2005).

39. See Teles, supra note 34 , at 78 (noting the "capacity of senior government officials . . . to move otherwise marginal ideas into the intellectual mainstream").

40. See Siegel, supra note 35, at 192-93 ("Heller's originalism enforces understandings . . . that were forged in the late twentieth century through [conservative] popular constitutionalism. . . . Heller respects claims and compromises forged in social movement conflict . . . in the decades after Brown v. Board of Education.") (citations omitted).

41. See Johnathan O'Neill, Originalism in American Law and Politics: A Constitutional History 111-32, 162-70 (2005); Steven M. Teles, The Rise of the Conservative Legal Movement: The Battle for Control of the LaW 145 (2008); Al Kamen \& Howard Kurtz, Theorists on Right Find Fertile Ground: Conservative Legal Activists Exert Influence on Justice Department, WASH. PosT, Aug. 9,1985 , at A1.

42. See Antonin Scalia, Originalism: The Lesser Evil, 57 U. CIN. L. Rev. 849,854 (1989) (" $[\mathrm{I}] \mathrm{t}$ is hard to discern any emerging consensus among the nonoriginalists as to what this might be."). 
their judges and Justices would use as their guiding interpretive philosophy. ${ }^{43}$

Judicial nominations play an important role in the construction and promotion of the name that the presidential administration wishes to promote. Nominations serve as a "focal point" permitting those inside and outside of an administration to coordinate themselves. ${ }^{44}$ Because of the stakes of judicial nominations, disparate interests will sit down across the table to debate and discuss their constitutional visions. These conversations can generate conflict about a name, but also move these interests closer towards a consensus about what that name should be. Stakeholders convened together recognize that without a name, their shared and separate interests will suffer. Indeed, this is a version of what happened during the Reagan Administration. ${ }^{45}$ Theorists outside of the government, lawyers inside of the government, and activists in between worked together to identify and agree on the originalism name as an initial frame. ${ }^{46}$ The converse of this is true, too: if an administration does not focus on generating a name, no focal point will be constructed, no multi-interest conversations will ensue, and no movement towards a naming consensus will result.

Once agreed upon, this name also serves as a pre-commitment devise shaping other nominations. ${ }^{47}$ It is easier to monitor the president selecting nominees, the Senate evaluating nominees, and the interest groups promoting or opposing nominees once their shared jurisprudential commitment has a name. Consider, for instance, the reaction of conservative interest groups once President George W. Bush nominated Harriet Miers and these interest groups learned she was not using the name or arguments associated with their originalist preferences. ${ }^{48}$

43. For an example of a book providing such names, see THE CONSTITUTION IN 2020 (Jack M. Balkin \& Reva B. Siegel eds., 2009).

44. See Richard H. McAdams, The Focal Point Theory of Expressive Law, in 7 ENCYClOPEDIA OF LAW AND ECONOMICS 167, 167 (Francesco Parisi ed., 2d ed. 2011) (describing a focal point as "mak[ing] mutually salient a particular way of coordinating behavior").

45. See Teles, supra note 34

46. Id.

47. See Jon Elster, Don't Burn Your Bridge Before You Come To It: Some Ambiguities and Complexities of Precommitment, 81 TeX. L. REV. 1751, 1754 (2003) ("When precommitting himself, a person acts at one point in time in order to ensure that at some later time he will perform an act that he could but would not have performed without that prior act. As I define it, precommitment requires an observable action, not merely a mental resolution.")

48. See Jonathan Riehl, Dissertation, The Federalist Society and Movement Conservatism: How a Fractious Coalition on the Right is Changing Constitutional Law and the Way We Talk and Think About It 1-5 (U. N.C.-Chapel Hill, 2007), 
Judicial nominations also play an important role in promoting the jurisprudential vision. For lower court nominations, the nomination by a president of a candidate affiliated with that name and the affiliated jurisprudential vision signals to the legal community that the president is serious about promoting that vision. Advocates making their case to the administration on policy and legal matters will know of the jurisprudential philosophy that the administration support. ${ }^{49}$ Lawyers arguing before judges appointed by the administration will know what types of arguments that judge is more likely to find convincing. ${ }^{50}$ Ambitious lawyers desiring a judicial or other nomination by the administration will know that familiarity with and usage of that name will help their chances. ${ }^{51}$

For Supreme Court nominations, naming plays this promotional role in the eyes of the public as well. ${ }^{52}$ Critical interest groups aspire to hold senators and presidents accountable for their nominations behavior and their consistency with particular jurisprudential commitments. ${ }^{53}$ With the exception of the rare Supreme Court decision that generates broad public debate-such as Roe v. Wade $e^{54}$ or Citizens United $v$.

https://cdr.lib.unc.edu/indexablecontent/uuid:a046e8b1-4e0b-4af8-8a08-cea9e5cb58a7 [https://perma.cc/ZSU9-WUWZ].

49. See Teles, supra note 34, at 66 (noting how originalism was an argumentative style used to persuade the Reagan Department of Justice of many initiatives).

50. See Nancy Scherer \& Banks Miller, The Federalist Society's Influence on the Federal Judiciary, 62 POL. RES. Q. 366 (2009) (finding that judges involved in the Federalist Society found certain types of arguments more convincing and deployed these arguments more frequently).

51. See David Kirkpatrick, '85 Document Opens Window to Alito Views, N.Y. Times (Nov. 15, 2005), http://www.nytimes.com/2005/11/15/politics/politicsspecial1/85-document-openswindow-to-alito-views.html [https://perma.cc/RDY6-55NP] (describing Samuel Alito's application to the Justice Department and its discussion of these conservative legal touchstones).

52. See Amy Goldstein \& Paul Kane, Liberalism Had Little Presence in Sotomayor Hearings, WASH. POST (July 19, 2009), http://www.washingtonpost.com/wpdyn/content/article/2009/07/18/AR2009071801787.html] [https://perma.cc/SC4R6MDC] (quoting critics of the Sotomayor confirmation hearings, including former University of Chicago Law School Dean saying that the confirmation hearings "did serious damage to the cause of progressive thought in constitutional law" and progressive activist Doug Kendall saying that it was "a totally missed opportunity. . . . The progressive legal project hit rock bottom [last] week").

53. For empirical evidence that they do, see Gregory A. Caldeira \& John R. Wright, Lobbying for Justice: Organized Interests Supreme Court Nominations, and United States Senate, 42 Am. J. Pol. ScI. 499 (1998); Jeffrey A. Segal et al., A Spatial Model of Roll Call Voting: Senators, Constituents, Presidents, and Interest Groups in Supreme Court Confirmations, 36 AM. J. PoL. SCI. 96 (1992).

54. 410 U.S. 113 (1973). 
F.E.C. ${ }^{55}$-the public is paying far greater attention to the judicial system during a Supreme Court nomination than at any other moment. ${ }^{56}$

The public does not pay great attention to the nuances of legal arguments, and so these confirmation hearings and the debates surrounding them generate a sense of what legal arguments are plausible and desirable. This sense is furthered if these arguments are framed together with a unifying name. ${ }^{57}$ The Senate confirmation hearing surrounding the nomination of Robert Bork to the Supreme Court, for instance, was seen as a public demonstration of the "intellectual seriousness" and salience of originalism. ${ }^{58}$ Chief Justice John Roberts described his role as that of an "umpire," that stimulated major public attention. ${ }^{60}$ Justice Sonia Sotomayor's remark earlier in her career that being a "wise Latina" ${ }^{61}$ could shape her jurisprudence likewise became a name that pervaded public discussion about her nomination.

Republican presidents have tended more openly to locate and promote judges who embrace the name originalism. ${ }^{62}$ Republican

55. 558 U.S. 310 (2010).

56. See generally James L. Gibson \& Gregory A. CAldeira, Citizens, COURTS AND CONFIRMATIONS: POSITIVITY THEORY AND THE JUdGMENTS OF THE AMERICAN PEOPle 8, 11 (2009).

57. See Amy Kapczynski, The Access to Knowledge Mobilization and the New Politics of Intellectual Property, 117 YALE L.J. 804, 813 (2008) ("Framing theory emerged out of the recognition that one cannot organize in concert with others to alter a set of material conditions without an interpretation of one's interests or grievances and theories of how to advance them.").

58. See Matthew J. Franck, The Originalist's Originalist, NAT'L REV. (Jan. 28, 2013), https://www.nationalreview.com/nrd/articles/337354/original-originalist [https://perma.cc/S3MD-WHRP].

59. Confirmation Hearing on the Nomination of John G. Roberts, Jr. to be Chief Justice of the United States Before the S. Comm. on the Judiciary, 109th Cong. 55 (2005) (statement of Judge John G. Roberts, Jr.) ("Judges are like umpires. Umpires don't make the rules, they apply them. The role of an umpire and a judge is critical. They make sure everybody plays by the rules, but it is a limited role. Nobody ever went to a ball game to see an umpire.").

60. See Bruce Weber, Umpires vs. Judges, N.Y. Times (July 11, 2009), http://www.nytimes.com/2009/07/12/weekinreview/12weber.html

[https://perma.cc/NVM5-H6WY] ("But since the Roberts hearings, the umpire metaphor has become synonymous, at least in public debate, with judicial restraint, the idea that judges are merely arbiters, that their job is not to set aside precedent and create law but to decide cases on the basis of established law.").

61. Sonia Sotomayor, A Latina Judge's Voice, 13 Berkeley La RAZA L.J. 87, 92 (2002) ("I would hope that a wise Latina woman with the richness of her experiences would more often than not reach a better conclusion than a white male who hasn't lived that life.").

62. See Dawn Johnsen, Lessons from the Right: Progressive Constitutionalism for the Twenty-First Century, 1 HARV. L. \& POL'Y REV. 239, 246 (2007) (“Although the practice of considering prospective judges' views is far from a recent development, 
presidents have indicated that they have a name for what they want from a judge or justice, and do not hide from that name. ${ }^{63}$ Individuals most prominently affiliated with generating that name are themselves nominated. Bork remains the most notable example of this. Bork was one of the theorists behind the creation of modern originalism. ${ }^{64}$ President Ronald Reagan nominated him to the Supreme Court, and he and his supporters referenced Bork's support of this name and vision of originalism as part of the reason to support his nomination. ${ }^{65}$ During his confirmation hearings, Bork embraced originalism rather than avoiding it. $^{66}$

The lesson supposedly learned from Bork's defeat was to hide legal views during hearings. ${ }^{67}$ Conservative nominees have therefore used the o-word less often explicitly, but still some of the time, and even when not using it directly have made arguments about judging that are part of the originalist project.

During the second Bush Administration, nominees to the lower federal courts reflected and reinforced these naming efforts. Law professor Michael McConnell was one of the most influential originalist

the Reagan/Meese reports stand out as unprecedented in their combination of great specificity, comprehensiveness, and sheer ambition.").

63. See Neil A. Lewis \& David Johnston, Bush Would Sever Law Group's Role in Screening Judges, N.Y. TIMES (Mar. 17, 2001), http://www.nytimes.com/2001/03/17/us/bush-would-sever-law-group-s-role-inscreening-judges.html [https://perma.cc/E6AF-VX5F] (compiling statements by candidate and then President George W. Bush indicating his desire for "originalist" Justices like Antonin Scalia and Clarence Thomas).

64. See Thomas B. Colby \& Peter J. Smith, Living Originalism, 59 DukE L.J. 239, 248 (2009) ("[S]cholars like Raoul Berger and Robert Bork, and political and judicial figures like Attorney General Edwin Meese III and then-Justice Rehnquist began to compose scholarly monographs articulating an intellectual defense of originalism in the 1970s and 1980s.").

65. See generally Ethan Bronner, BAtTle for Justice: How the Bork NOMINATION SHOOK AMERICA (2007) (compiling statements of Bork supporters referencing him during his nomination as an originalist).

66. See Linda Greenhouse, The Bork Hearings: Bork's Testimony Ends with Panel Still Deeply Split, N.Y. TIMES (Sept. 20, 1987), http://www.nytimes.com/1987/09/20/us/the-bork-hearings-bork-s-testimony-ends-withpanel-still-deeply-split.html?pagewanted=all [https://perma.cc/QNS7-UEEV] ("For more than an hour, Senator Arlen Specter, Republican of Pennsylvania, engaged Judge Bork in a dialogue that ranged over many constitutional issues but focused on one that lies at the heart of the debate over Judge Bork's confirmation: the nominee's insistence that the original intent of the framers is the only valid guide in interpreting the Constitution.").

67. See, e.g., Elena Kagan, Confirmation Messes, Old and New, 62 U. CHI. L. Rev. 919, 920 (1995) (reviewing Stephen L. Carter, The Confirmation Mess (1994)) (noting the incentives after the Bork defeat for the Senate to "cease[] . . . engag[ing] nominees in meaningful discussion of legal issues"). 
constitutional theorists in the academy at the time. ${ }^{68}$ During his confirmation hearing to be a judge on the United States Court of Appeals for the Tenth Circuit, he largely embraced his earlier views, even attacking Griswold v. Connecticut ${ }^{69}$ and Roe v. Wade by name. ${ }^{70}$ McConnell provided an originalist defense of the invalidity of laws criminalizing polygamy. ${ }^{71}$ When Janice Rogers Brown was nominated to the United States Court of Appeals for the District of Columbia Circuit, she likewise rejected Griswold as unmoored in originalist constitutional understandings. ${ }^{72}$ When Brett Kavanaugh-a former clerk to Bork-was nominated to the D.C. Circuit, he rejected any sense that the Constitution was living. ${ }^{73}$

However, naming has been perceived as tactically problematic for the Democratic Party because it is uncooperative. The language of technical competence dominates public discourse about judicial nominations. ${ }^{74}$ Presidents, senators, and interest groups focus on the qualifications of nominees. Discussion of litmus tests related to a jurisprudential name are disavowed by those on both sides of the political aisle. ${ }^{75}$ When President Barack Obama introduced Elena Kagan

68. See, e.g., Michael W. McConnell, Originalism and the Desegregation Decisions, 81 VA. L. REV. 947, 955 (1995) (arguing that "[a]n originalist approach in Brown would have paved the way for a more powerful judicial assault on the Jim Crow laws of the South"). See also David G. Savage, Liberals at Odds Over Appeals Court Nominee, L.A. TIMES (Sept. 16, 2002), http://articles.latimes.com/2002/sep/16/nation/na-mcconnell16

[https://perma.cc/CQ4T-SB9N] ("Yale law professor Akhil D. Amar, a liberal constitutional scholar, calls McConnell 'America's preeminent scholar of religious liberty.' The University of Chicago's Cass R. Sunstein, a liberal constitutional theorist, calls him "extraordinarily able, one of the best constitutional scholars in the country."”).

69. 381 U.S. 479 (1965).

70. Confirmation Hearing on the Nomination of Michael McConnell To Be Circuit Judge For The Tenth Circuit, Before the S. Comm. on the Judiciary, 107th Cong. 350, 383 (2002).

71. Id. at $354,377-79$.

72. Confirmation Hearing on the Nomination of Janice R. Brown, Of California, To Be Circuit Judge For The District of Columbia Circuit, Before the S. Comm. on the Judiciary, 108th Cong. 62 (2003).

73. Confirmation Hearing on the Nomination of Brett Kavanaugh To Be Circuit Judge For The District of Columbia Circuit, Before the S. Comm. on the Judiciary, 109th Cong. 45 (2006).

74. See GIBSON \& CALDEIRA, supra note 56, at 11 (noting the salience of the argument "that the nominee ought to be judged primarily (if not exclusively) on legalistic criteria like judiciousness").

75. See Peter Baker, Obama Promises No 'Litmus Test' for Supreme Court Nominee, N.Y. TIMES (Apr. 21, 2010, 11:38 AM), https://thecaucus.blogs.nytimes.com/2010/04/21/obama-promises-no-litmus-test-forsupreme-court-nominee/ [https://perma.cc/X99V-TQBF] ("President Obama said on Wednesday that he has no abortion litmus test as he selects a replacement for Justice John Paul Stevens.”). 
as his Supreme Court nominee, he mentioned that she was "one of the nation's foremost legal minds," and he mentioned several times during the Senate's consideration of her that she clerked for the Supreme Court. ${ }^{76}$ Names are supposed to signal partiality rather than the objectivity that presidents and senators are supposed to desire from their judicial nominees. With better filtration mechanisms, we all know that judges nominated by Democratic presidents tend to be more liberal than those nominated by Republican presidents, ${ }^{77}$ but to admit this and desire this openly can be an uncooperative political act.

Democrats working on judicial nominations have argued that naming is therefore counterproductive because of the excessive cost generated by it. A judicial nominee who uses the name affiliated with a governing judicial philosophy-such as using the phrase "living constitutionalism"-places a bullseye on his or her back. Interest groups pull the "fire alarm" " and notify relevant senators of the problematic nominee. ${ }^{79}$ Senators from the party of the president elected from swing states will be less inclined to support the nominee. ${ }^{80}$ Senators from the opposing party are more likely to use the many

76. See Remarks by the President and Elena Kagan at Reception Honoring Her Confirmation (Aug. 6, 2010), https://obamawhitehouse.archives.gov/the-pressoffice/2010/08/06/remarks-president-and-elena-kagan-reception-honoring-herconfirmation [https://perma.cc/8P2Q-RSWV]; see also Peter Baker \& Jeff Zeleny, Obama Picks Kagan, Scholar but Not Judge, for Court Seat, N.Y. TIMES (May 10, 2010), http://www.nytimes.com/2010/05/11/us/politics/11 court.html?pagewanted =all [https://perma.cc/U4CF-2Y2F].

77. See Lawrence Baum \& Neal Devins, Split Definitive: For the First Time in a Century, the Supreme Court is Divided Solely by Political Party, $\begin{array}{lllll}\text { SLATE } & \text { (Nov. } & \text { 2011, } & 5: 27 & \text { PM), }\end{array}$ http://www.slate.com/articles/news_and_politics/jurisprudence/2011/11/supreme_court s_partisan_divide_and_obama_s_health_care_law.html [https://perma.cc/LCQ4$\bar{S}$ U8D] ("For the first time in a century, the Supreme Court is divided solely by political party.").

78. Nancy Scherer, Brandon L. Bartels \& Amy Steigerwalt, Sounding the Fire Alarm: The Role of Interest Groups in the Lower Federal Court Confirmation Process, 70 J. Pol. 1026, 1029 (2008).

79. See Nancy Scherer, Brandon L. Bartels \& Amy Steigerwalt, Sounding the Fire Alarm: The Role of Interest Groups in the Lower Federal Court Confirmation Process (unpublished manuscript) ("[W]e theorize that a principal function of interest groups in the lower court confirmation process is to act as 'fire marshals' for the Senate. By alerting the Senate to problematic nominees, interest groups aid the Senate in its constitutional mission under Article II to provide 'advice and consent' to the president on all life-tenured federal court nominations.").

80. See Jonathan P. Kastellec et al., Public Opinion and Senate Confirmation of Supreme Court Nominees, 72 J. PoL. 767, 769 (2010) (reporting data finding that senatorial votes on Supreme Court nominations by senators are shaped by state-level public opinion). 
procedural roadblocks that Senate rules afford senators from the minority party. ${ }^{81}$

The argument is one sounding in the tactical benefits of avoiding candor. ${ }^{82}$ The same nominee presented to the Senate without using the name affiliated with his or her jurisprudential approach does not generate the costs imposed by political opponents. That nominee is therefore more likely to become a judge promoting that approach if he or she does not use the name affiliated with the approach when nominated. Nominees that have the potential to promote the name of the jurisprudence supported by the presidential administration would do better to disavow their preferences in favor of neutral, technocratic preferences. ${ }^{83}$

The additional costs of naming are also harder to endure for a Democratic administration because of the supposed absence of political supports. Overcoming the additional vetogates put in front of a naming nominee requires constituencies who are willing to expend political resources on judicial nominations. Interest groups like the Judicial Crisis Network pledged to spend $\$ 10$ million to secure the confirmation of Neil Gorsuch to the Supreme Court. ${ }^{84}$ Republican primary voters want to hear from their candidates that they will nominate committed originalists to the bench. ${ }^{85}$ It is more challenging for the Democratic Party to mobilize such efforts on behalf of judicial nominations.

The result is that the Obama Administration avoided this naming dynamic. Their first judicial nominee was David Hamilton, nominated

81. See, e.g., Carl Tobias, Sixth Circuit Federal Judicial Selection, 36 U. CAL. Davis L. ReV. 721, 735-36 (2003).

82. See Micah Schwartzman, Judicial Sincerity, 94 VA. L. REV. 987, 1018 (2008) (explaining that candor may "require that judges disclose everything they believe is relevant").

83. See President Obama Nominates Pamela Harris to Serve on the United States Court of Appeals, WHITE House (May 8, 2014), https://obamawhitehouse.archives.gov/the-press-office/2014/05/08/president-obamanominates-pamela-harris-serve-united-states-court-appeal [https://perma.cc/56NYBXEF] ("Throughout her career, Pamela Harris has shown unwavering integrity and an outstanding commitment to public service.").

84. See Burgess Everett, Conservatives Plan \$10 Million High Court Ad Campaign, POLITICO (Jan. 9, 2017, 5:13 http://www.politico.com/story/2017/01/supreme-court-trump-schumer-conservatives233315 [https://perma.cc/Z5F5-DZ7F].

85. See Neil A. Lewis, The 2000 Campaign: The Judiciary; Presidential Candidates Differ Sharply on Judges They Would Appoint to Top Courts, N.Y. TIMES (Oct. 8, 2000), http://www.nytimes.com/2000/10/08/us/2000-campaign-judiciarypresidential-candidates-differ-sharply-judges-they-would.html [https://perma.cc/9U5DK6WC] ("Governor [George W.] Bush, after meeting with his advisers, decided to offer an explicit and hard-to-mistake signal and said that the justices he most admired were Antonin Scalia and Clarence Thomas.”). 
by President Obama to serve on the United States Court of Appeals for the Seventh Circuit. Hamilton was selected precisely because he was not affiliated with any overarching jurisprudential agenda. ${ }^{86}$ The argument for not naming was one based in the logic of reciprocal cooperation: by naming someone not affiliated with any liberal vision, the goal of the Obama Administration was aiming to "reduce the partisan contentiousness of judicial confirmation battles of recent years. " ${ }^{87}$ Hamilton received the same treatment during his hearings and in the votes in committee and on the Senate floor that a candidate more known for and embracing naming would have received. ${ }^{88}$ The result was simple: a respected Seventh Circuit judge but one without any discernible benefit for an alternative vision of the law, and yet one who required the same expenditure of political effort and generated the same opposition as a naming judge.

This pattern recurred often during the eight years of the Obama Administration. Nominees affiliated with the efforts to create a liberal alternative to originalism were rarely seriously considered, let alone nominated. When candidates like this were nominated, efforts were immediately made to distance themselves from any naming efforts. President Obama mentioned his desire for a justice that was guided by empathy, defined as "understanding and identifying with people's hopes and struggles." 89 Justice Sotomayor, though, rejected the empathy label and any other liberal name or jurisprudential vision during her confirmation hearings. ${ }^{90}$

86. See Lewis, supra note 19 ("The administration official said part of the reason for making the Hamilton nomination the administration's first public entry into the often contentious field of judicial selection was to serve 'as a kind of signal' about the kind of nominees Mr. Obama will select. The official spoke on the condition of anonymity because the nomination had not been officially made."); Toobin, supra note 19 ("The hope was that Hamilton's appointment would begin a profound and rapid change in the confirmation process and in the federal judiciary itself.").

87. Lewis, supra note 19.

88. See David Fontana, Going Robe, New RePublic (Sept. 16, 2009), https://newrepublic.com/article/71929/going-robe [https://perma.cc/JS8L-6UJF].

89. Press Briefing by Press Secretary Robert Gibbs, WhITE HousE (May 1, 2009), https://obamawhitehouse.archives.gov/the-press-office/press-briefingpress-secretary-robert-gibbs-5-1-09 [https://perma.cc/Z7CN-9JPE] (statement of President Obama).

90. See Goldstein \& Kane, supra note 52 ("The hearings were a moment of history that liberals had awaited for 15 years: an opportunity for a Democratic president's Supreme Court nominee to inject into the public dialogue fresh ideas about the Constitution and the law, beginning to recalibrate a court that has gravitated to the right. Yet Sotomayor did not articulate such a vision. In answering Cardin, and in scores of other times during four intense days in the witness chair, she eluded efforts of Democrats and Republicans alike to draw out any statement of liberal thought."). 
Goodwin Liu was actively involved in the American Constitution Society for Law and Public Policy and widely known as a scholar advocating progressive understandings of the Constitution. When he was nominated to the Ninth Circuit, The Washington Post proclaimed that his nomination "energized the left" ${ }^{91}$ because of these features of his background. During his nomination process, Liu's supporters disavowed any sentiment like that-and Liu eventually did so himself. Liu rejected Justice Sotomayor's "wise Latina" remarks. ${ }^{92} \mathrm{He}$ rejected the idea of a "living Constitution." ${ }^{93} \mathrm{He}$ described himself as embracing the originalist name, stating that he is committed to "the original meaning of constitutional provisions where original meaning refers to 'the underlying principles that the Framers' words were publicly understood to convey . . . ." ${ }^{94} \mathrm{He}$ disavowed his own earlier argument that the Constitution might reflect a concern with social and economic inequalities. ${ }^{95}$

The absence of naming also creates its own incentive structure within the field of judicial nominations. It is individually rational for nominees to avoid naming even if it is not collectively rational for presidential administrations to do so. The individual nominee who names simply makes themselves the subject of a fire alarm and increases their chances of being rejected for the federal bench. Interest groups opposed to the candidate are mobilized because of the unusual practice of a nominee engaging in naming. Interest groups can then successfully mobilize senators to oppose the candidate. The nominees who are confirmed are therefore those who do not name, which incentivizes the President to nominate other nominees who do not name.

The point of this Essay is that this rejection of naming was tactically unwise. Refusing to name means that jurisprudence is being played using the other team's rulebook. Lawyers and judges are left making arguments for their perspective using the linguistic and rhetorical tools developed for the opposing perspective. Lawyers and

91. See Robert Barnes, Law Professor Goodwin Liu May Be Test Case for Obama Judicial Picks, WASH. Post (Mar. 22, 2010), http://www.washingtonpost.com/wpdyn/content/article/2010/03/21/AR2010032102581.html [https://perma.cc/889NLPWU].

92. Responses of Goodwin Liu, Nominee to be U.S. Circuit Judge for the Ninth Circuit to the Written Questions of Senator Jeff Sessions 78, SENATE JUDICIARY COMMITTEE, https://www.judiciary.senate.gov/imo/media/doc/GoodwinLiu-QFRs.pdf [https://perma.cc/4ZYK-N469].

93. See id. at 6 .

94. Id. at 31.

95. Id. at 3,43 . 
judges are left to communicate to their political and public supporterslet alone their legal ones-using the tools that are known to be utilized previously by their strongest opponents. Lawyers and judges desire to make arguments that can be considered "off the wall" because their perspectives have not been named and therefore elaborated.

The failure to name during the judicial nominations process of the Obama Administration was a substantial lost opportunity. The past decade has featured the most sustained effort among liberal academics, judges, and justices to devise a name and a vision for their jurisprudence in at least a generation. The first year of the Obama Administration featured an edited book by Jack Balkin and Reva Siegel entitled The Constitution in 2020, featuring a series of essays meant to respond to the Reagan Administration's blueprint The Constitution in $2000 .{ }^{96}$ Justice Stephen Breyer authored a book in $2005^{97}$ and then one again in 2011 meant to provide a liberal alternative to originalism. ${ }^{98}$ Jack M. Balkin's book Living Originalism in 2011 likewise aimed to provide scaffolding for a liberal jurisprudential vision. ${ }^{99}$ These attempts to provide a name and a vision did not feature in the remarks of President Obama's judicial nominees, who instead largely either raised the names and visions associated with originalism and umpires, or responded to questions about them. Contrast that with the energy surrounding originalism in the 1980's, and how that energy was manifested through confirmation hearings like those of Bork to the Supreme Court in 1987.

This is not only a problematic state of affairs for a Democratic administration, but an unnecessary one. The evidence suggests that naming does not clearly elicit greater obstruction in a political environment as polarized as the present one. Supreme Court nominations are a unique political animal, but in the past era naming did not seem to matter that much, except on the extremes with Bork. An ideologically diverse cohort of Supreme Court Justices since 1955 have been unanimously confirmed or confirmed with close to no

96. The Constitution In 2020, supra note 43, at 1-7.

97. See Michael W. McConnell, Active Liberty: A Progressive Alternative to Textualism and Originalism?, 119 HARV. L. REV. 2387, 2389 (2006) (reviewing Stephen J. Breyer, Active Liberty: Interpreting Our Constitution (2005)) (noting how Breyer is attempting to articulate an alternative theoretical infrastructure).

98. See David Fontana, Stephan Breyer's "Making Democracy Work," Reviewed by David Fontana, WASH. Post. (Oct. 3, 2010), http://www.washingtonpost.com/wpdyn/content/article/2010/10/01/AR2010100103520.html [https://perma.cc/6RXG4XAF].

99. See Jack M. Balkin, Living Originalism 277-80 (2011). 
opposition. ${ }^{100}$ Now, naming does not matter much because partisanship predicts Supreme Court confirmation votes rather than these votes being unanimous or close to it. Notice, for instance, the unified opposition by the Republican Senate to confirming the eminently qualified Merrick Garland to the Supreme Court in 2016. Garland had purposefully avoided affiliation with any efforts to name and promote a liberal jurisprudential vision. ${ }^{101}$

For lower court nominations, naming likewise seems not to generate substantially greater opposition because partisanship is what matters. Nominees like David Hamilton-likewise focused on technical qualifications and not jurisprudential causes ${ }^{102}$-were opposed on a party-line basis. Hamilton was filibustered by Senate Republicans, voted out of committee on a party-line vote, and confirmed 59-39 (with only one Republican senator, his longtime supporter Richard Lugar, voting for him).

Selecting nominees that engage in naming generates political supports that do not exist rather than relying on fixed political supports that do not exist. Voters follow the priming of the leaders of their political parties. ${ }^{103}$ Richard Nixon campaigned against the Warren Court and argued that judges should "interpret the law, not make the law." 104 The Reagan Administration made a particular view of the judicial role a central part of its agenda. ${ }^{105}$ George W. Bush told Republican primary voters the two models for a Supreme Court nominee in his Administration, ${ }^{106}$ and then-candidate Trump provided Republican primary voters with a list of twenty-one conservative judges he would consider for his Supreme Court nominee. ${ }^{107}$ After all, a

100. Harry Blackmum, John Paul Stevens, Anthony Kennedy, Sandra Day O'Connor, and Antonin Scalia were unanimously confirmed, and Ruth Bader Ginsburg and Stephen Breyer faced minimal opposition. See Geoffrey Stone, Understanding Supreme Court Confirmations, 2010 SuP. CT. REV. 381, 389-90 (2011).

101. See Carl Hulse, Supreme Court Showdown Could Shape
Fall https://www.nytimes.com/2016/03/17/us/politics/supreme-court-nomination-obamacongress.html?_r $=0$ [https://perma.cc/YTJ2-B22R].

102. See supra note 86 and accompanying text.

103. For a nice summary, see Robert B. Cialdini et al., A Focus Theory of Normative Conduct: Recycling the Concept of Norms to Reduce Littering in Public Places, 58 J. Personality \& Soc. Psychol. 1015, 1024-25 (1990).

104. See O’NeILl, supra note 41, at 96 (quoting President Nixon).

105. See Teles, supra note 34.

106. See Lewis, supra note 85 ("Governor [George W.] Bush, after meeting with his advisers, decided to offer an explicit and hard-to-mistake signal and said that the justices he most admired were Antonin Scalia and Clarence Thomas."),

107. See Adam Liptak, Trump's Supreme Court List: Ivy League? Out. The Heartland? In., N.Y. TIMES (Nov. 14, 2016), https://www.nytimes.com/2016/11/15/us/politics/trump-supreme-court-justices.html 
Supreme Court with eight Republican nominees refused to overrule Roe v. Wade, ${ }^{108}$ and a Supreme Court with five Republican nominees found a right to same-sex marriage in the Constitution, ${ }^{109}$ so conservatives were already primed to care about judicial nominations.

A candidate that names an approach to the law can create precisely the cognitive prime to generate similar political resources on the political left. A nominee known previously for his or her devotion to naming who then engages in naming during their confirmation process signals to their supporters the sincerity and seriousness of his or her devotion to the jurisprudential cause. ${ }^{110}$ The name itself that he or she uses can motivate and mobilize supporters more. The importance of "empathy" in judging and the benefits of a "wise Latina" on the bench are arguments that resonate with liberal styles of political reasoning and would motivate political liberals. If originalism was meant to motivate those who believe in literalism and those who believe in a better past wrongly distorted by the complicated present, ${ }^{111}$ then liberal names can motivate those who believe in the importance of diversity and inclusion, even when federal judges interpret legal texts.

This naming by nominees can compensate for in motivation what has been the absence of salient Supreme Court harms to motivate the progressive cause. The most widely known Supreme Court cases are all progressive victories. ${ }^{112}$ Cases like United States $v$. Lopez ${ }^{113}$ did not generate the practical implications that conservatives desired and

[https://perma.cc/3JQ8-4X9Z] ("When Donald J. Trump issued his final list of 21 potential nominees to the Supreme Court in September, he made a vow. 'This list is definitive,' he said, "and 'I will choose only from it in picking future Justices of the Supreme Court." ").

108. Planned Parenthood of Se. Pa. v. Casey, 505 U.S. 833, 845-46 (1992).

109. Obergefell v. Hodges, 135 S. Ct. 2584, 2585 (2015).

110. Kahan, supra note 36, at 73 (noting how these names serve as "signals that are received by intermediary groups-including politicians and media commentators-who then amplify and retransmit them to members of the cultural groups who look to them for guidance").

111. See Greene, supra note 36, at 704-09 (highlighting the appeal of originalism); Peter J. Smith \& Robert W. Tuttle, Biblical Literalism and Constitutional Originalism, 86 Notre DAME L. REV. 693 (2011) (making similar arguments).

112. See Paul Bedard, Poll: Roe v. Wade Most Well-Known Case, Only 34\% Know 'Bush v. Gore,' WASH. EXAMiner (Oct. 1, 2015, 12:05 PM), http://www. washingtonexaminer.com/poll-roe-v.-wade-most-well-known-case-only-34know-bush-vs.-gore/article/2573195 [https://perma.cc/6V4V-VAR2] (reporting that the most well-known conservative win in the Supreme Court was Bush v. Gore, known by only one-in-three respondents).

113. 514 U.S. 549 (1995). 
progressives feared. ${ }^{114}$ Citizens United v. F.E.C. might serve as the progressive Roe $v$. Wade in the future. ${ }^{115}$

The Senate's refusal to vote on Merrick Garland could be the appointments-related cause that mobilizes progressives in the way that Bork's defeat mobilized conservatives. Garland, though, was not a mobilizing defeat in the way that Bork's defeat was. ${ }^{116}$ Garland was a creature of the Washington legal establishment, rather than a lawyer or judge dedicating to branding and directing that legal establishment with naming or jurisprudence. ${ }^{117}$

One other note on naming is in order. Naming can be effective even if the nominee engaged in the task does not have a realistic chance of being confirmed-because, for instance, the Senate is controlled by the party opposing the President (as it was for President Obama his last two years in office). The Bork nomination is a great example of this. Even in defeat, it consolidated conservative senators and interest groups behind originalism, and gave originalism a microphone louder than it had ever had previously. As Douglas NeJaime has written about litigation, there can even be a unique value in losing legal battles. ${ }^{118}$

114. See Edward L. Rubin, Puppy Federalism and the Blessings of America, 574 AnNAls AM. ACAD. POL. \& Soc. SCI. 37, 38 (2001) (describing Lopez as "puppy federalism" because "like puppy love, it looks somewhat authentic but does not reflect the intense desires that give the real thing its inherent meaning").

115. See Matea Gold \& Anne Gearan, Hillary Clinton's Litmus Test for Supreme Court Nominees: A Pledge to Overturn Citizens United, WASH. Post (May 14, 2015), https://www.washingtonpost.com/news/post-politics/wp/2015/05/14/hillaryclintons-litmus-test-for-supreme-court-nominees-a-pledge-to-overturn-citizensunited/?utm term $=.86 \mathrm{~d} 49093264 \mathrm{f}$ [https://perma.cc/U9LB-49DN] ("Hillary Clinton told a group of her top fundraisers Thursday that if she is elected president, her nominees to the Supreme Court will have to share her belief that the court's 2010 Citizens United decision must be overturned.").

116. See Editorial Board, Merrick Garland for the Supreme Court, N.Y. Times (Mar. 16, 2016), https://www.nytimes.com/2016/03/17/opinion/merrickgarland-for-the-supreme-court.html [https://perma.cc/MRM3-ERCW] ("If you tried to create the ideal moderate Supreme Court nominee in a laboratory, it would be hard to do better than Judge Merrick Garland.").

117. See Sheryl Gay Stolberg et al., Merrick Garland is a Deft Navigator of Washington's Legal Circles, N.Y. TIMES (Mar. 26, 2016), https://www.nytimes.com/2016/03/27/us/politics/merrick-garland-obama-supremecourt-

nominee. $h t m l$ mtrref $=$ www.google. com $\& g w h=3 C 5 A A 676 B 671 B B 05 F D 4 A 29 C 54 C 2$ AF505\&gwt=pay [https://perma.cc/6D94-7G7D] ("[I]t became clear over time that Mr. Garland was silently working out his arguments, processing facts and testing alternatives. Surrounded by overachievers in a city full of people clamoring to be heard, he was waiting until he had something to say.").

118. See Douglas NeJaime, Winning Through Losing, 96 IowA L. ReV. 941, 941 (2006) ("Sophisticated advocates may use litigation loss (1) to construct organizational identity and (2) to mobilize constituents."). 


\section{NUMBING}

One other dimension of nominations accomodationism has to do with what I will call "numbing." Not all potential or actual nominees are created equal. Presidential administrations and their supporters can use unusually provocative nominees with great power. An administration or its supporters can "plant" the name of a potential extreme nominee in the media, ${ }^{119}$ or actually nominate that candidate. This numbs the political system by generating nominee "extremeness aversion." 120 Political resources are directed towards opposing this nominee or ensuring that no additional similar nominees are selected, thereby directing oppositional resources away from other potential or actual nominees. Political elites and public opinion are cognitively distorted by the possibility of this nominee, making other nominees seem less objectionable.

Many features of a potential or actual nominee can make him or her unusually provocative. Because of his or her youthful age, a nominee can be significant because he or she will serve on the bench for a long time and could be nominated to a higher position at a later time. ${ }^{121}$ When President George W. Bush nominated Miguel Estrada to the United States Court of Appeals for the District of Columbia Circuit in 2001, the fact that he was only thirty-nine years old made him an unusually threatening nominee to the Democratic Party. ${ }^{122}$ Potential or actual nominees that have a prior profile that is significant enough to give them a potentially outsized microphone from the bench can also be unusually provocative. Nominating Robert Bork to the Supreme Court in 1987-given his prior work on originalism-made him unusually

119. See David E. Pozen, The Leaky Leviathan: Why The Government Condemns and Condones Unlawful Disclosures of Information, 127 HARV. L. REV. 512, 534 (2013) ("Plants are taken to be 'authorized' disclosures designed to advance administration interests and goals. Leaks are 'unauthorized' disclosures.") (citations omitted).

120. For a discussion of extremeness aversion more generally, see Itamar Simonson \& Amos Tversky, Choice in Context: Tradeoff Contrast and Extremeness Aversion, 29 J. MARKETING Res. 281 (1992). See also Mark Kelman et al., Context-Dependence in Legal Decision Making, 25 J. Legal STUD. 287 (1996) (considering extremeness aversion in the legal context).

121. See Fontana \& Schwartzman, supra note 11 (identifying the importance of nominating younger judges).

122. See Mark Greenbaum, Double Take, New RePublic (May 2, 2010), https://newrepublic.com/article/74728/double-take [https://perma.cc/CNF3-L7LC] ("The same qualities that had earned him a nomination-his youth, political leanings, and minority background-perversely worked against him: Fearing that Estrada would sit atop a list of possible Supreme Court picks once he became a judge, Senate Democrats waged a harsh two-year campaign against him."). 
provocative. ${ }^{123}$ Potential or actual nominees that promise to be more jurisprudentially extreme can also be unusually provocative. When President Trump was considering William J. Pryor for the Supreme Court in 2017, commentators described him as "the most polarizing" potential nominee because of many provocative comments over the years, ${ }^{124}$ including his testimony before the Senate Judiciary Committee when nominated to the Eleventh Circuit that Roe v. Wade had led to the "slaughter of millions of unborn children." 125

Numbing has several tactical benefits. First, numbing directs resources towards the potential or actual extreme nominee and away from other nominees. Opposition interest groups conduct opposition research on that potential nominee to be able to demonstrate how extreme that potential nominee is. ${ }^{126}$ Opposition interest groups solicit contributions from their supporters by mentioning their efforts to prevent and/or defeat that nominee. Senators from the opposing party inform the administration of the problems with such an extreme nominee. The media features stories documenting the extreme jurisprudential perspectives of the potential nominee, and get prominent sources on the record to state that this potential nominee is extreme.

Meanwhile, other potential nominees benefit from the resources expended on the extreme nominee by not facing the same degree of scrutiny. Opposition interest groups have not compiled the dossier on or motivated their supporters to oppose other nominees. Senators have not signaled to the administration their sentiments on other nominees, leaving an administration capable of claiming less opposition for that nominee. Media coverage of other nominees explicitly or implicitly contrasts them with the more extreme nominee.

123. See Bruce Ackerman, Transformative Appointments, 101 HaRv. L. REv. 1164, 1164 (1988) ("[W]hen judged by normal personal and professional criteria, Robert Bork is among the best qualified candidates for the Supreme Court of this or any other era.").

124. See Kimberly Kindy, Pryor: Perhaps the Most Polarizing Supreme Court

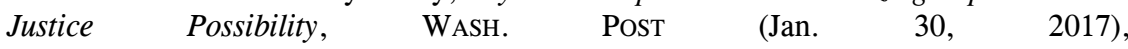
https://www.washingtonpost.com/national/pryor-perhaps-the-most-polarizing-supremecourt-justice-possibility/2017/01/28/f25bb7e2-e4ae-11e6-ba1163c4b4fb5a63_story.html?utm_term =.fb1ef15d8eda [https://perma.cc/VKL6-LGXG].

125. See Opinion, Beyond the Pale, N.Y. TIMES (June 23, 2003), http://www.nytimes.com/2003/06/23/opinion/beyond-the-pale.html [https://perma.cc/RR7L-J44M].

126. See Scherer, Bartels \& Steigerwalt, supra note 79 ("[W]e theorize that a principal function of interest groups in the lower court confirmation process is to act as 'fire marshals' for the Senate. By alerting the Senate to problematic nominees, interest groups aid the Senate in its constitutional mission under Article II to provide 'advice and consent' to the president on all life-tenured federal court nominations."). 
Second, numbing shapes elite and public sentiments towards the actual or potential nominee. Political attention rarely focuses on judicial nominees, particularly for the lower federal courts. Interest groups sound the "fire alarm" that the nominee is extreme. ${ }^{127}$ When these same citizens hear that the fire did not transpire-that the extreme nominee was not nominated or that relatively few extreme nominees were selected-they are less concerned about the other nominees. After Bork was defeated, a conservative federal judge like Douglas Ginsburg did not seem as extreme. ${ }^{128}$ Likewise, after President Trump did not nominate Pryor, a conservative federal judge like Neil Gorsuch did not seem as extreme. ${ }^{129}$

Numbing also has a signaling benefit for the president. It signals to relevant lawyers and judges what jurisprudential perspectives are "on the wall" and "off the wall." ${ }^{130}$ Lawyers aspiring to judicial (or other) nominations in that administration is thereby authorized to move jurisprudentially towards the extreme nominee, since that extreme nominee was at least considered-and was possibly nominated-for a powerful federal judicial position. Empirical studies have demonstrated that judges behave strategically when desiring elevation, so the trickledown effects on state judges or lower federal courts seeking elevation could be substantial. ${ }^{131}$

Consider, for instance, the situation surrounding George W. Bush's nomination of Janice Rogers Brown to the D.C. Circuit. Brown was described as manifesting "evidence of extremism." 132 Brown had described liberalism as flawed in the same way that slavery was. ${ }^{133}$ While one or two senators will often attended many hearings for presidential nominees, senatorial attention to Brown was substantial.

127. Scherer, Bartels \& Steigerwalt, supra note 78, at 1026.

128. See Robert Pear \& Jeff Gerth, Court Choice in Focus: A Portrait of Ginsburg, N.Y. TIMES (Nov. 1, 1987), http://www.nytimes.com/1987/11/01/us/courtchoice-in-focus-a-portrait-of-ginsburg.html?pagewanted=all [https://perma.cc/FFK2FZ2W] (covering Ginsburg's nomination by asking whether he is "another Bork" and quoting one expert as stating "on the social agenda, I think he's no Bork").

129. See Kindy, supra note 124 (contrasting Gorsuch with Pryor by labeling Gorsuch not as "polarizing” as Pryor).

130. See Jack M. Balkin, How Social Movements Change (Or Fail To Change) the Constitution: The Case of the New Departure, 39 Suffolk U. L. Rev. 27, 28 (2005).

131. See Ryan C. Black \& Ryan J. Owens, Courting the President: How Circuit Court Judges Alter Their Behavior for Promotion to the Supreme Court, 60 AM. J. POL. SCI. 30 (2016) (finding such effects).

132. David D. Kirkpatrick, New Judge Sees Slavery in Liberalism, N. Y. TIMES (June 9, 2005), http://www.nytimes.com/2005/06/09/politics/new-judge-sees-slaveryin-liberalism.html?_r=0 [https://perma.cc/LBJ8-PD7G].

133. See id. 
Senator Dick Durbin from Illinois, one of the leaders of the Senate Democrats, attended her hearings with many prepared and complicated questions. ${ }^{134}$ Then-Senator Barack Obama made a speech from the Senate floor opposing Brown. ${ }^{135}$ The list of those on the record before the Senate opposing her nomination was enormous and unusual. ${ }^{136}$

This distraction generated lesser scrutiny for other candidates the Senate was considering around the same time. Senate Democrats during the Bush Administration focused their opposition on provocative nominees like Brown and Pryor, and were forced to justify this obstruction by noting that "the Senate has confirmed dozens of judicial nominees with little or no debate." 137 Nominees that would normally be provocative sailed through the confirmation process-relatively speaking at least-because the system had been numbed by nominees like Brown and Pryor. Diane Sykes, later considered a strongly conservative federal judge on the Seventh Circuit, was confirmed 70-27 without anywhere near the opposition while Brown and Pryor's nominations were pending. ${ }^{138}$ Brett Kavanaugh, a young and talented Bush White House staffer, was nominated in January of 2006 with much fanfare and controversy. ${ }^{139}$ The opposition resources he consumed meant those resources were not directed at another young and talented nominee, Neil Gorsuch-later to be nominated to the Supreme Courtwho sailed through on a voice vote.

134. Judgment Call: The Nomination of Justice Roger Brown; The Economist's Bill Emmott; Faith and the Law; Polio, MOYers \& Co. (Oct. 31, 2003) http://billmoyers.com/content/judgement-call-economist-bill-emmott-wendykaminer2faith-law-polio/ [https://perma.cc/R74F-DH8D].

135. 151 CONG. REC. S6,178-80 (daily ed. June 8, 2005) (statement of Sen. Obama).

136. See id. at $\mathrm{S} 218$.

137. See Carl Hulse \& David Stout, Embattled Estrada Withdraws as Nominee for Federal Bench, N.Y. Times (Sept. 4, 2003), http://www.nytimes.com/2003/09/04/politics/embattled-estrada-withdraws-as-nomineefor-federal-bench.html [https://perma.cc/FDX8-XPM2].

138. See Kevin Russell \& Charles Davis, Potential Nominee Profile: William Pryor (Expanded), SCOTUSBLOG (Jan. 10, 2017, 3:35 PM), http://www.scotusblog.com/2017/01/potential-nominee-profile-william-pryor [https://perma.cc/3729-526F] ("President-elect Donald Trump mentioned . . . [Sykes] by name during a primary debate shortly after Scalia's death . . . .").

139. See Neil A. Lewis, Bush Aide on Court Nominees Faces Fire Himself, N.Y. TIMES (Apr. 28, 2004), http://www.nytimes.com/2004/04/28/us/bush-aide-oncourt-nominees-faces-fire-as-nominee-himself.html [https://perma.cc/SS6P-GGN5] ("So when Mr. Kavanaugh came before the Senate Judiciary Committee on Tuesday as a nominee himself for an appeals court post, no one was surprised when he was verbally batted around by the panel's Democrats, who have complained that Mr. Bush is trying to tilt the nation's courts rightward."). 
Other actual nominees had written records that suggested a jurisprudential perspective so provocative that they also distorted perspectives of the ideological positions of other nominees. When President Trump considered Pryor for the Supreme Court, progressive interest groups like the Alliance for Justice went on the record opposing Pryor specifically as ideologically extreme. ${ }^{140}$ The New York Times favorably contrasted Gorsuch with Pryor, whose "credentials, erudition and more muted stances" were discussed "as compared with Judge Pryor." 141

For the cooperative political actor, numbing is problematic. A youthful nominee is meant to capture a scarce seat on the federal bench potentially for half a century, meaning that many later presidentsincluding presidents of the opposing political party-will not have the opportunity to select their own preferred candidate for that seat. A prominent nominee will use his or her seat to criticize the jurisprudential perspective of the opposing party for decades to come. The standard statement issued by senators is that nominees will be evaluated to ensure they are within the mainstream, ${ }^{142}$ and so provocative nominees violate that announced standard.

The logic, therefore, of rejecting numbing is that it generates additional political costs without any corresponding political benefits. Members of the opposing party are provoked by these nominees. Think of, for instance, the greater attention and opposition that Bork elicited. This is true of the lower federal courts as well. The Senate filibuster for lower court nominations was abolished by Senate Democrats because of its usage by Republicans against nominees like Liu.

The Obama Administration therefore largely rejected the numbing strategy, purposefully, and from the beginning of its time in office. ${ }^{143}$ Nominees like Hamilton were put forward because they were not extreme. In his second term, President Obama did utilize numbing more frequently. Nina Pillard was nominated to the D.C. Circuit the same day and at the same ceremony as the more establishment Washington lawyer Patricia Millett and sitting federal judge Robert

140. See Kindy, supra note 124 (contrasting Gorsuch with Pryor by labeling Gorsuch not as "polarizing” as Pryor).

141. See Michael D. Shear \& Adam Liptak, A Supreme Court Pick is Promised. A Political Brawl is Certain, N.Y. Times (Jan. 24, 2017), https://www.nytimes.com/2017/01/24/us/politics/supreme-court-nominees-trump.html [https://perma.cc/Z29Z-LDJN].

142. See The Latest: White House Plans Major Outreach by Gorsuch, DENVER Post (Jan. 31, 2017, 8:40 PM), http://www.denverpost.com/2017/01/31/trump-neilgorsuch-supreme-court/ [https://perma.cc/6ACD-JLZC] (quoting Senate Minority Leader Charles Schumer, D-NY).

143. See Lewis, supra note 19 and accompanying text. 
Wilkins. ${ }^{144}$ Pillard immediately galvanized opposition from conservatives, thereby distracting attention from Millett and Wilkins. ${ }^{145}$

The tactical merits of Obama Administration's reticence to engage in numbing more often are questionable. The political costs of a provocative nominee are not necessarily any greater than the political costs of any nominee. Senate opposition to candidates can be based on a manufactured sense that a judicial nominee is provocative, even if he or she is not. The opposition to Liu, for instance, was based on a sense from his scholarly writings that he could be more aggressive as a progressive judge. ${ }^{146}$ His age (thirty-nine at the time of his nomination) and his political connections (he was a co-author of an article with Hillary Clinton ${ }^{147}$ ) suggested a potentially influential judge who could later be elevated to the Supreme Court. David Hamilton, by contrast, was selected by President Obama precisely because he did not seem provocative. ${ }^{148}$ However, conservative groups described him as having a "pretty clear leftist record" and labeled him the first pro-abortion judicial candidate nominated by President Obama. ${ }^{149}$

Meanwhile, the political supports behind the President's nominee can be even greater with a candidate meant to numb the opposition. Political supports are often built in support of or opposition to cases-

144. Michael D. Shear \& Jeremy W. Peters, Judicial Picks Set the Stage for a Battle in the Senate, N.Y. TIMES (June 4, 2013), http://www.nytimes.com/2013/06/05/us/politics/obama-to-name-3-to-top-appeals-courtin-challenge-to-republicans.html?hp [https://perma.cc/3A2L-QS7S].

145. See Sergio Munoz, Working Moms' Family Planning is Extreme and Radical: Right-Wing Attacks on Judicial Nominee Jump to Fox, MEDIAMATTERS (Nov. 25, 2013, 5:43 PM), https://mediamatters.org/blog/2013/11/25/working-moms-familyplanning-is-extreme-and-rad/197053 [https://perma.cc/WFP4-3UUU] (quoting Carrie Severino of the conservative Judicial Crisis Network stating that "Nina Pillard is probably the most extreme judge that has been nominated for this court and possibly for any court in the country"); see, e.g., Grunwald, supra note 20 (reporting that "White House sources" had "figured [Pillard] . . . would be a sacrificial lamb, a scalp Republicans could claim while confirming Millett, an uncontroversial appellate lawyer, and hopefully Wilkins, an African-American judge who had been confirmed unanimously to the D.C. district court in 2010").

146. See Robert Barnes, supra note 91 ("[Liu] is an outspoken advocate of liberal causes, including same-sex marriage and affirmative action.”).

147. See Hillary Rodham Clinton \& Goodwin Liu, Separation Anxiety: Congress, The Courts, and The Constitution, 91 GEO. L.J. 439 (2003).

148. See Toobin, supra note 19 ("Hamilton had been vetted with care. After fifteen years of service on the trial bench, he had won the highest rating from the American Bar Association; Richard Lugar, the senior senator from Indiana and a leading Republican, was supportive; and Hamilton's status as a nephew of Lee Hamilton, a well-respected former local congressman, gave him deep connections.").

149. See Steven Ertelt, President Barack Obama Makes First Pro-Abortion Judicial Pick in David Hamilton, LIFENEWS (Mar. 17, 2009, 9:00 AM), http://www.lifenews.com/2009/03/17/nat-4920/ [https://perma.cc/8G9Q-BS7X]. 
such as Roe v. Wade-but also in response to nominees like Robert Bork. Just like a plaintiff like James Obergefell or Lily Ledbetter, a provocative nominee puts a face and a story on a perspective on the law. So, for instance, the nomination of Liu, according to The Washington Post, "energized the left." ${ }^{150}$ Newspapers reported his inspiring personal story, ${ }^{151}$ just as they had done about Miguel Estrada (the Bush D.C. Circuit nominee) nearly a decade earlier. ${ }^{152}$ The provocative nominee provides additional political resources, rather than minimizing them.

Consider public opinion regarding the nomination of Merrick Garland to the Supreme Court in 2016. Garland was not the jurisprudentially transformative figure that Bork was or another nominee could have been. The refusal of Senate Republicans to consider his nomination, though, made him a cause celebre. Republicans had long been a party more focused on judicial nominations. Polling during the 2016 presidential election, though, found that members of both parties agreed almost equally with the statement that it "was very important to them personally" what happened with the opening on the Supreme Court created by the untimely death of Justice Antonin Scalia. ${ }^{153}$

\section{NUMBERS}

Another effective but aggressive strategy in nominating judges that remained relatively under-utilized during the Obama Administration compared to the Bush Administration was simultaneously to nominate large numbers of federal judges simultaneously. ${ }^{154}$ The numbers

150. Barnes, supra note 91.

151. See id. ("Born to Taiwanese immigrants, he learned English at schools in the South before attending Stanford, where he was a Rhodes Scholar, and Yale Law School. He clerked for Justice Ruth Bader Ginsburg, worked in the Clinton administration and became active in education reform. Liu won a distinguished teaching award at the University of California's Berkeley School of Law and was promoted to associate dean.").

152. See Hulse \& Stout, supra note 137 (referencing Estrada as "[a] Honduran immigrant and a graduate of Harvard Law School").

153. See Garland Nomination to Supreme Court Gets Positive Reaction FROM THE PUBLIC, PEW RES. CTR. (2016), http://www.peoplepress.org/files/2016/03/3-28-2016-Supreme-Court-release.pdf [https://perma.cc/7ACDVY9Y].

154. This point is essentially about the nomination of lower court judges. President Obama nominated two Justices to the United States Supreme Court, but these nominations could not have been simultaneous because Justice John Paul Stevens did not resign until after Sonia Sotomayor had been confirmed. See Letter from John Paul Stevens, Supreme Court Justice, to Barack Obama, President (April 9, 2010), 
strategy is one more applicable to the nomination of judges below the level of the Supreme Court. Discussions about judicial nominations focus almost exclusively on the total number of federal judges nominated by a President. ${ }^{155}$ The distribution of these nominations across political time is also important. Presidential administrations that nominate larger volumes of judges simultaneously generate greater oversight costs for the opposing party in the Senate and their supportive interest groups. Scarce political capital for the opposing party is depleted rapidly and substantially by more nominees, while political capital in support of these nominees is ready and potentially increased because of more nominees. Larger volumes of simultaneous nominees also generate pressure to confirm some significant number of these nominees, so as to blunt any problematic narrative about Senate obstruction.

The scarcity of political resources is a definitional feature of political life. The expenditure of political resources generates both a direct cost and an opportunity cost taxing these scarce resources. Political actors only have so many resources to investigate a policy and decide their position on that policy. Political actors only have so many resources to persuade other stakeholders of their position on that policy. Political actors only have so many resources to generate public attention for and move public opinion towards their position on that policy. Scarcity means that resources invested in one policy dimension can become asset-specific resources, not readily transferable to deploy to address some other policy dimension. ${ }^{156}$

Scarcity can be a particular challenge for those in political opposition because of the first-mover advantage of many of those in power. ${ }^{157}$ When a political actor proposes a policy, it is often the

https://www.supremecourt.gov/publicinfo/press/JPSLetter.pdf [https://perma.cc/F5ETMT5X] ("I shall retire from regular active service as an Associate Justice.").

155. See, e.g., Carl Tobias, Filing the Appellate Court Vacancies, 17 U. PA. J. Const. L. 1, 1 (2015) ("President Obama has named more judges than Presidents George W. Bush and Bill Clinton had at this juncture in their tenure, while courts of appeals currently have the fewest openings since 1990."); Grunwald, supra note 20 ("Obama has already appointed 329 judges to lifetime jobs, more than one third of the judiciary.”).

156. See Peter Alexis Gourevitch, The Governance Problem in International Relations, in Strategic Choice AND InTERnAtional Relations 137, 144-45 (David A. Lake \& Robert Powell eds., 1999) ("Political actors develop investments, 'specific assets,' in a particular arrangement-relationships, expectations, privileges, knowledge of procedures, all tied to the institutions at work. . . . [This] helps to explain institutional persistence. [A]ctors . . . have incentives to protect their investment by opposing change.").

157. See Terry M. Moe \& William G. Howell, The Presidential Power of Unilateral Action, 15 J.L. ECON. \& ORG. 132, 138 (1999) ("[P]residents are particularly well suited to be first-movers . . . . The other branches are then presented 
culmination of an investment of substantial resources in the development of that policy. That initial investment has yielded epistemic and stakeholder infrastructure to defend that policy once announced. The opponent of that policy, meanwhile, is put on the defensive, left to generate and consolidate his or her resources immediately or face rapid defeat and/or claims of obstruction of the policy. The political science literature about the power of setting the agenda, for instance, finds unsurprisingly that those in power set the agenda in a way that leaves the opposition disadvantaged. ${ }^{158}$ Because of the scarcity of their political resources, opponents are usually left pulling the "fire alarm" for only the most problematic of political actions engaged in by the majority. ${ }^{159}$

Judicial nominations are susceptible to this same logic of scarcity in opposition. The primary opposition to the president's judicial nominations within government come from members of the opposing party on the Senate Judiciary Committee. The docket of that committee is sufficiently large that judicial nominations are just one small part of the issues that members of that Committee are considering. ${ }^{160}$ There are only roughly nine senators and maybe double that number of lawyers working for those senators for the opposition party on the Senate Judiciary Committee. There are interest groups active on judicial nominations-such as the Alliance for Justice on the left and the Judicial Crisis Network on the right-but there are not many of them. ${ }^{161}$ There are interest groups that focus on a range of issues, including judicial nominations, such as the AFL-CIO. ${ }^{162}$ For those working on

with a fait accompli, and it is up to them to respond. If they are unable to respond effectively, or decide not to, the president wins by default. And even if they do respond, which could take years, he may still get much of what he wants anyway.”).

158. For a discussion of the power of agenda-setting, see FrANK R. Baumgartner \& Bryan D. Jones, AgEndas AND Instability in AMERICAN Politics (2d ed. 2009).

159. See Mathew D. McCubbins \& Thomas Schwartz, Congressional Oversight Overlooked: Police Patrols Versus Fire Alarms, 28 AM. J. PoL. SCI. 165, 166 (1984) (defining "fire alarms" in conducing oversight as reviewing just the most problematic of actions).

160. See Jurisdiction, COMM. ON JUDICIARY, https://www.judiciary.senate.gov/about/jurisdiction [https://perma.cc/7JWL-M6X2] (defining committee jurisdiction as "providing oversight" and "consideration of nominations and legislation, resolutions, messages, petitions, memorials and other matters") (last visited Mar. 13, 2017).

161. See Scherer, Bartels \& Steigerwalt, supra note 78, at 1028 (listing some of the groups most actively involved in judicial nominations).

162. See AFL-CIO, The Senate Should Do ITS Job ON FEDERAL JUDICIAL APPOINTMENTS (2016), http://www.aflcio.org/content/download/174597/4155029/file/The\%20Senate\%20Shoul 
judicial nominations, it can be easier generating public attention related to a Supreme Court nomination, ${ }^{163}$ but not for lower court nominations, making the task of mobilizing a larger opposition to a nomination quite challenging.

The first-mover advantage can also be large for judicial nominations. If one of the senators from the state of the judicial nomination is both from the opposing party and on the Senate Judiciary Committee, then the opposition party will have advance notice of the nominee and an opportunity to prepare opposition to that nominee. Otherwise, the president and his or her supporters in the Senate will have extensive background information available to them about the nominee at the moment of the nomination, while opponents will be left scrambling to learn about the nominee. Because our federal judicial system is geographically distributed, ${ }^{164}$ Senate lawyers and supportive interest groups in Washington can be left researching a trial lawyer in Idaho nominated to the federal district court there. A nominee like David Souter or Harriet Miers leaves opponents scrambling. ${ }^{165}$

A judicial nomination is often the culmination of a process of lining up supporters rather than the beginning of that process. Before announcing a nominee, the president's staff will not just look into candidates from within the administration, but also line up supporters outside of the administration. Organizations like the Alliance for Justice or the Federalist Society for Law and Public Policy are consulted prior

d\%20Do\%20Its \% 20Job\%20on\%20Federal\%20Judicial\%20Appointments \%20-

\%20FINAL.pdf [https://perma.cc/C97D-2FZW].

163. See GIBSON \& CALDEIRA, supra note 56, at 71-72 (finding that approximately three-quarters of Americans reported that it was important that their senators vote "correctly"); James G. Gimpel \& Robin M. Wolpert, Opinion-Holding and Public Attitudes Toward Controversial Supreme Court Nominees, 49 PoL. Res. Q. 163, 164 (1996) (reporting that senatorial vote on Supreme Court nominations shaped their vote total in subsequent elections); Kastellec et al., supra note 80 (reporting statelevel data finding effects on senatorial vote totals).

164. See Sharon E. Rush, Federalism, Diversity, Equality, and Article III Judges: Geography, Identity, and Bias, 79 Mo. L. REV. 119, 130 (2014) ("The Framers solidified this important relationship between the Article III judiciary and the states by providing in the Constitution that the Senate must approve the President's judicial nominees.").

165. See Opinion, For David Souter, With Hope, N.Y. TIMES (Sept. 27, 1990), http://www.nytimes.com/1990/09/27/opinion/for-david-souter-withhope.html?login=email [https://perma.cc/6ZHA-2UXU] (describing Souter as "[v]irtually unknown even to scholars"); see Timothy R. Williams, Bush Names Counsel as Choice for Supreme Court, N.Y. TIMES (Oct. 3, 2005), http://www.nytimes.com/2005/10/03/politics/politicsspecial1/bush-names-counsel-aschoice-for-supreme-court.html [https://perma.cc/FQY6-8JB8] ("Ms. Miers . . . has never been a judge, and therefore lacks a long history of judicial rulings that could reveal ideological tendencies. Her positions on such ideologically charged issues as abortion and affirmative action are unclear."). 
to the selection of a nominee, often to brainstorm the names of potential nominees. ${ }^{166}$ President Trump's list of twenty-one potential Supreme Court nominees was compiled with the assistance of several of these organizations, ${ }^{167}$ but this consultation often transpires prior to a nomination. When the White House releases the name of a judicial nominee, its supporters are already armed and ready for political battle, while its opponents have not even started to contemplate who to oppose or how to oppose them.

If scarcity is a political reality related to judicial nominations, particularly for those in opposition, it is far from inevitable. There are, after all, only nine Justices on the Supreme Court and 874 Article III judges. President Obama inherited only fifty-nine openings on the federal bench when he became president in January of 2009. ${ }^{168}$ President Obama only nominated ten judges or justices during the first six months of his Administration. ${ }^{169}$ The evidence suggests that the Obama Administration nominated fewer numbers of judges during their first six months as a willful attempt to signal respect to Republican Senators by making it easier for them to evaluate these judges. ${ }^{170}$ Fire alarms are only needed to respond to judicial nominations when there are so many fires that police patrols are impossible ${ }^{171}$-and there need not be many judicial nominations fires.

Therefore, one means of making salient the resource scarcity of opposition to judicial nominees is to nominate a large number of candidates simultaneously because political capital rarely can be increased proportionally in response. Senate and interest group staffing cannot be increased substantially and immediately, since both tend to utilize fiscal year funding that could not be changed until the next fiscal year. This leaves finite number of staff members researching large numbers of nominees. Stakeholders within and outside of the Senate must be redeployed to focus on opposing the nomination. Meanwhile, those supportive of the nomination from within the administration, the

166. See, e.g., Scherer, Bartels \& Steigerwalt, supra note 78, at 1028 n.5; Scherer \& Miller, supra note 50, at 367.

167. See Liptak, supra note 107.

168. Rucker \& Barnes, supra note 2 .

169. Jeffery L. Viken, Roberto A. Lange, Irene C. Berger, Charlene Honeywell, Gerald E. Lynch, Andre M. Davis, David Hamilton, Beverly B. Martin, Joseph A. Greenaway, Jr., and Sonia Sotomayor.

170. See Lewis, supra note 19 ("By naming judges one at a time, Mr. Obama is taking a markedly different approach from former President George W. Bush, who held a ceremony on May 9, 2001, in the Rose Garden to present his first 11 choices for appeals court seats. The ceremony provided a political air to the nominations, most of which went to prominent conservatives.").

171. See McCubbins \& Schwartz, supra note 159, at 166 (defining police patrols as comparatively "centralized, active and direct"). 
Senate, the interest group community, and the home state of the nominee have been mobilized and are prepared with their justifications for the nominee.

Depleted political resources can be replenished over time. Opposition research that could not be done on a nominee one week can be done the next week. Interest groups that cannot be convened one week can be convened the next week. The simultaneous strategy, though, prevents that from transpiring.

Multiple simultaneous nominations also place pressure on the opposing party in the Senate to confirm some of these nominees. ${ }^{172}$ The more nominees being held up in the Senate at any given time, the easier it is for the president and the media to target the opposing party for playing politics with judicial nominations. ${ }^{173}$ This leaves the opposition party with an undesirable choice. The opposing party in the Senate can spend few resources to target each nominee, or a lot of resources to target a few nominees. If it pursues the first course of action, it will struggle to defeat any nominee because not enough opposition will notice the nomination and mobilize against it. If it pursues the second course of action, it will mean that the rest of the nominees-who could also be provocative-will more easily be confirmed as a result of the absence of opposition.

President George W. Bush utilized the simultaneous nominations strategy many times. He nominated eleven judges to the courts of appeals on one day in September of $2001 .^{174}$ Included within that list were several notable conservative judges. ${ }^{175} \mathrm{He}$ nominated five to the appellate courts on the same day in January of 2003 and two more

172. See Micah Schwartzman, Not Getting Any Younger: President Obama's Penchant for Older Judges Scuttled Goodwin Liu, SLATE (May 26, 2011, 6:04 PM), http://www.slate.com/articles/news and politics/jurisprudence/2011/05/not getting an y_younger.html [https://perma.cc/458D-AVLX] ("For example, had they been isolated cases, it is doubtful that Janice Rogers Brown, William Pryor, or Priscilla Owen would have been confirmed. But there was safety in numbers. With a large group of controversial nominees, some of them were bound to make it.").

173. Press Release, Senator Patrick Leahy, Senate Makes Progress to Fill Judicial Vacancies (May 8, 2014), https://www.leahy.senate.gov/press/senate-makesprogress-to-fill-judicial-vacancies [https://perma.cc/3UJP-4SVZ] ("Today, there are 74 judicial vacancies throughout the country. At the same point under President Bush in May 2006, there were 50 judicial vacancies.").

174. See Neil A. Lewis, Bush to Nominate 11 to Judgeships Today, N.Y. TIMES (May 9, 2001), http://www.nytimes.com/2001/05/09/us/bush-to-nominate-11-tojudgeships-today.html [https://perma.cc/3UJP-4SVZ].

175. See id. ("The first nominees, 11 candidates for the federal appeals courts, include several outspoken conservatives who are committed to profound change on issues like the separation of church and state and increasing states' rights."). 
within the next month. ${ }^{176}$ In February of 2005, he nominated six to appellate courts. ${ }^{177}$

Senate Democrats were left with limited resources to respond. When John Roberts was nominated to the United States Court of Appeals for the District of Columbia Circuit in 2003 as part of the simultaneous nominations of that year, it was known at the time that was a potential future Supreme Court nominee. ${ }^{178}$ Because of the volume of nominees, though, Senate Republicans successfully moved to have Roberts testify the same day before the Senate Judiciary Committee as several other nominees. ${ }^{179}$ Other prominent Bush nominees-such as Neil Gorsuch, President Trump's Supreme Court nominee-did not receive much attention by overwhelmed Senate Democrats and were therefore unanimously confirmed. ${ }^{180}$

By contrast, the Obama Administration largely avoided simultaneous nominations. ${ }^{181}$ There was only one day during his first term when he nominated more than two judges to a federal court of appeals. ${ }^{182}$ The moments when the Obama Administration did attempt this strategy illustrated the merits of the strategy. On June 4, 2013, President Obama stood "[i]n a formal Rose Garden ceremony normally

176. See Neil A. Lewis, Bush Selects Two for Bench, Adding Fuel to Senate Fire, N.Y. TIMES (July 26, 2003), http://www.nytimes.com/2003/07/26/us/bushselects-two-for-bench-adding-fuel-to-senate-fire.html [https://perma.cc/2SY4-S2BK] ("President Bush escalated his fight with Senate Democrats over judicial nominations today by naming two [more] candidates for judgeships for the federal appeals court in Washington, widely regarded as second in importance only to the Supreme Court."); Opinion, Steamrolling Judicial Nominees, N.Y. TIMES (Feb. 6, 2003), http://www.nytimes.com/2003/02/06/opinion/steamrolling-judicial-nominees.html [https://perma.cc/SF9X-ZM8H] ("The new Senate Republican majority is ushering in an era of conveyor-belt confirmations of Bush administration judicial nominations.”).

177. Bush Administration Nominations by Date, White House, https://georgewbush-whitehouse.archives.gov/news/nominations/ [https://perma.cc/W3ZB-F47F] (last visited Mar. 13, 2017).

178. See Lewis, supra note 174.

179. See Opinion, supra note 176 ("Republicans on the Judiciary Committee held a single hearing last week for three controversial appeals court nominees.").

180. See Carl Hulse, In Neil Gorsuch's Confirmations, Parsing the Meaning of "Yes," N.Y. TIMES (Feb. 11, 2017), https://www.nytimes.com/2017/02/11/us/politics/neil-gorsuch-supreme-courtconfirmation.html [https://perma.cc/GX8H-ZC4W] ("Republicans on the Judiciary Committee held a single hearing last week for three controversial appeals court nominees.").

181. See, e.g., Lewis, supra note 19 ("By naming judges one at a time, Mr. Obama is taking a markedly different approach from former President George W. Bush, who held a ceremony on May 9, 2001, in the Rose Garden to present his first 11 choices for appeals court seats. The ceremony provided a political air to the nominations, most of which went to prominent conservatives.").

182. Shear \& Peters, supra note 144. 
reserved for Supreme Court hopefuls and prominent cabinet nominees." ${ }^{183} \mathrm{He}$ nominated three candidates for the D.C. Circuit, at least one of whom (Cornellia T.L. Pillard) was more controversial. ${ }^{184}$ This was immediately perceived by Senate Republicans as a noncooperative act. ${ }^{185}$ All three were confirmed, ${ }^{186}$ with Pillard absorbing the brunt of the attacks by Republican senators and with only limited resources remaining to evaluate and attack the other two D.C. Circuit nominees. ${ }^{187}$

The cooperative behavior of nominating fewer numbers of judges did not generate a differential and more cooperative response by Senate Republicans. Hamilton was the only Obama nominee to the court of appeals for a few weeks and attracted lots of attention and opposition from Republican senators. ${ }^{188}$ When more judges are nominated simultaneously, the same motivation to oppose these nominees is present-but the ability to do so is less pronounced because of resource scarcity. If anything, then, simultaneous nomination of large numbers of nominees reduces political opposition. The motivation to oppose is constant, but the opportunity to do so is limited.

Simultaneous nominees can increase the political capital available to the president and his or her nominees. For political supporters, simultaneous nominations of large numbers of nominees is a signal that the president is serious about the cause of judicial nominations and serious about pursuing that cause. The president is signaling that his or

183. Id.

184. See id. ("Ms. Pillard's background may prove a bit more problematic. She served in the Clinton administration and has worked at the American Civil Liberties Union and the NAACP Legal Defense and Educational Fund, two well-known liberal organizations.").

185. See id. ("There's a culture of intimidation throughout the executive branch," Mr. McConnell said after the president's announcement. "There's also a culture of intimidation here in the Senate.").

186. Cornelia T.L. Pillard, U.S. CT. ApPEAlS D.C. Circuit, https://www.cadc.uscourts.gov/internet/home.nsf/Content/VL +-+Judges +- + NP [https://perma.cc/XNC3-K2G5] (last visited Mar. 13, 2017); Robert L. Wilkins, U.S. CT. APPEALS D.C. https://www.cadc.uscourts.gov/internet/home.nsf/Content/VL +-+Judges +-+RLW [https://perma.cc/6VVX-F699] (last visited Mar. 13, 2017); Patricia A. Millett, U.S. CT. APPEALS D.C. https://www.cadc.uscourts.gov/internet/home.nsf/Content/VL+-+Judges +-+PAM [https://perma.cc/F9BB-6XLC] (last visited Mar. 13, 2017).

187. Michael D. Shear \& Jeremy W. Peters, Judicial Picks Set the Stage for a Battle in the Senate, N.Y. TIMES (June 4, 2013) http://www.nytimes.com/2013/06/05/us/politics/obama-to-name-3-to-top-appeals-courtin-challenge-to-republicans.html?hp [https://perma.cc/PN3A-2W7K].

188. Jeremy W Peters, Republicans Again Reject Obama Pick for Judiciary, N.Y. TIMES (Nov. 12, 2013), http://www.nytimes.com/2013/11/13/us/politics/senateblocks-judicial-nominee-with-filibuster.html [https://perma.cc/9BM9-RAC3]. 
her administration has been expending substantial political resources to locate large numbers of nominees, and is willing to expend these resources to ensure these nominees are confirmed. This cost endured by the administration makes simultaneous nominations a credible signal of seriousness on the issue. ${ }^{189}$ Interest groups are therefore more likely to expend their limited resources pushing for these nominees. Meanwhile, supporters of the president hear from and are informed by him or her that this is an important issue, which stimulates supporter interest and activity.

\section{CONCLUSION}

Since Ronald Reagan became President of the United States in 1981, the Democratic Party has been playing defense on judicial nominations. The Republican Party made finding their most talented legal minds and putting them on the federal bench a major priority. Many of the great theorists of the jurisprudential right-Michael McConnell, Richard Posner, Antonin Scalia-went from the academy to the bench. ${ }^{190}$ Many of the great lawyers of the jurisprudential rightJohn Roberts, Jeffrey Sutton-went from practice to the bench. ${ }^{191}$ These superstars before the bench became superstars on the bench, writing opinions that are widely known, ${ }^{192}$ and sending their law clerks on to

189. See Michael Spence, Job Market Signaling, 87 Q.J. ECON. 355, 358-61 (1973) (noting famously the power of costly signals).

190. Michael W. McConnell, STANFORD LAW ScH., https://law.stanford.edu/directory/michael-w-mcconnell/\#slsnav-key-works

[https://perma.cc/YJ7W-5MRM] (last visited Mar. 13, 2017); Richard A. Posner, U. CHI. LAW SCH., http://www.law.uchicago.edu/faculty/posner-r [https://perma.cc/N4LZ-XFEM] (last visited Mar. 13, 2017); Antonin Scalia, OYEZ, https://www.oyez.org/justices/antonin_scalia [https://perma.cc/2X2B-5ZMZ] (last visited Mar. 13, 2017).

G. Roberts,

$J r$.

OYEZ, https://www.oyez.org/justices/john_g_roberts_jr [https://perma.cc/7EHT-WHEG] (last visited Mar. 13, 2017); Hon. Jeffrey S. Sutton, FEDERALIST Soc'y, http://www.fedsoc.org/experts/detail/jeffrey-s-sutton [https://perma.cc/67T7-J927] (last visited Mar. 13, 2017).

192. Think of, for instance, how important it was that Judge Sutton voted to uphold the constitutionality of the Affordable Care and Patient Protection Act in 2011. See Thomas More Law Ctr. v. Obama, 651 F.3d 529, 549, 565-66 (6th Cir. 2011) (Sutton, J., concurring); Andrew Cohen, Judge Sutton's Opinion Deserves a Closer Look, ATLANTIC (June 29, 2011), https://www.theatlantic.com/national/archive/2011/06/aca-judge-suttons-opiniondeserves-a-closer-look/241258/ [https://perma.cc/5QDL-GSM3] ("The Bush appointee and former clerk to Justice Scalia [Sutton] surprisingly rules in favor of the health care law ....."). 
become the next generation of elite lawyers and law professors. ${ }^{193}$ Presidents Clinton and Obama, both former law professors, did not put together the nominations record to match what happened when a Republican was in the White House.

Lawyers on the left watched with disappointment, but also with awe and admiration. Conservatives had admired the liberal legal movement's success in the Warren Court years inside and outside of court, and aspired to create the organizational structure to emulate it. Now, a generation later, liberals feel the same. ${ }^{194}$ They wanted their own president to transform the federal courts in their favored direction. Just as the Federalist Society looked to liberals a generation ago for a roadmap to success, Democrats have started to believe that identifying the triumphs of conservatives on judicial nominations is a good place to start.

The argument of this Essay has been that the institutional practices of judicial nominations have generated a discrete list of political strategies that work better for presidents trying to maximize their nominations successes. These strategies feature certain common dimensions that mean that just as they worked for past Republican presidents, they could have worked for President Obama and can work for future Democratic presidents. The road to future nominations success for Democrats involves staying in the same lines that Republican presidents have created.

Staying in those lines, though, involves a political ethos that has largely been lacking in the Democratic Party for at least a generation: a willingness aggressively to prioritize and push judicial nominations. President Obama's limitations on judicial nominations were not the result of losing a brutal political fight, but of largely not starting one at all. The past several years have witnessed a resurgence of energy in the Democratic Party, and a desire to revisit political tactics. Regardless of the ideological preferences of voters or officials, there has been a gradual trend towards pursuing these preferences with a renewed intensity. Past institutional norms that Democratic Party leaders refused to flout have now been reframed as norms that can be leveraged tactically to achieve maximum outputs. With this motivation to engage in more aggressive political tactics, the next Democratic president could

193. See William E. Nelson, Harvey Rishikof, I. Scott Messinger \& Michael Jo, The Liberal Tradition of the Supreme Court Clerkship: Its Rise, Fall and Reincarnation?, 62 VAND. L. REV. 1749, 1775-78 (2009) (highlighting the importance the conservative legal movement placed on clerkships); Brad Snyder, The Judicial Genealogy (and Mythology) of John Roberts: Clerkships from Gray to Brandeis to Friendly to Roberts, 71 OHIO ST. L.J. 1149, 1216-25 (2010) (discussing the importance of clerkships to Roberts's career).

194. TELES, supra note 41, at 22-57. 
have the opportunity to do what the past few Democratic presidents have not: use available and aggressive political strategies to create a federal bench that they find desirable. 